\title{
Wealth Creation and Managerial Pay: MVA and EVA as Determinants of Executive Compensation
}

\author{
Anand S. Desai* \\ Ali Fatemi** \\ Jeffrey P. Katz*
}

First Draft: December 1997

This Version: January 1999

* College of Business Administration, Kansas State University, Manhattan, KS 66506-0503. ** College of Commerce, DePaul University, 1 East Jackson Blvd., Chicago, IL 60604-2287. Please do not quote. All comments are welcome and should be forwarded to the first author. Previous versions of this paper were presented at The Institute for Corporate Planning, Technical University of Berlin, Germany (December, 1997), and at the 1998 Global Finance Conference in Mexico City, Mexico (April, 1998). 


\title{
Wealth Creation and Managerial Pay: MVA and EVA as Determinants of Executive Compensation
}

\begin{abstract}
The design of incentive compatible executive-compensation policies is a crucial element for firms that seek a competitive advantage in an effort to maximize owner wealth. In this paper, we examine the relationship between executive compensation and measures of firm performance that capture the economic profit earned by the firm, namely, EVA and MVA. We test the hypothesis that after controlling for risk, these measures are more effective measures of wealth creation and hence executive compensation. We find that firm size and risk are related to the pay of top executives. We also find evidence that top manager pay is related to market value added to the firm during the year. By grouping firms into cohorts based on polar performance (high/low) for each performance measure, we are able to provide additional insights about executive compensation. By controlling for the relative level of performance, executive compensation plans reward top managers for their relative level of contribution to the wealth of owners.

Finally, we assess whether top manager pay is an incentive for future performance or reward for past behavior. Our evidence suggests that top managers are incented to increase the EVA of the firm but are also rewarded for past additions the market value as measured by MVA.
\end{abstract}




\section{Wealth Creation and Managerial Pay: MVA and EVA as Determinants of Executive Compensation}

\section{Introduction}

Optimal executive compensation contracts perfectly align the interests of the executives with those of the firm's shareholders (e.g. see Harris and Raviv, 1979, Grossman and Hart, 1983). Such an optimal contract will (1) act as an incentive mechanism for the executives to engage in the maximization of the firm's value and (2) appropriately reward the executives for such behavior. Whether executive compensation contracts meet this test of optimality, ex-ante or ex-post, is an empirical question. For obvious reasons, academics, compensation committees, policy makers, the press and the public all have a keen interest in the findings of such empirical works.

In order to identify the determinants of executive pay, a number of researchers have examined relationships between different measures of firm performance and top manager pay. ${ }^{1}$ For example, Murphy (1985) finds a statistically significant relationship between the level of pay and performance. Mehran (1995) finds that firm performance is positively related to management's ownership stake and to the percentage of its compensation that is equity-based. However, Jensen and Murphy (1990) do not find a significant relationship between changes in firm value and changes in executive compensation. Hadlock and Lumer (1997) find that payperformance sensitivities have increased over time. Specifically, they find that for the largest firms the sensitivities for the 1934-40 period were not significantly different than for the 1974-86 period. However, the sensitivities have significantly increased over time for smaller firms.

\footnotetext{
${ }^{1}$ Firm performance has been measured in many different ways (see meta-analysis by Tosi, Werner, Katz \& GomezMejia, 1997), including profits (Agarwal, 1981), return on equity (Kroll, Simmons, \& Wright 1990), return on assets (Pavlik \& Belkaoui, 1991) change in profits (Leonard, 1990; Winn \& Shoenhair, 1988), profit as a percent of sales (Deckop, 1988), market return (Jensen \& Murphy, 1990, Hadlock and Lumer 1997), composite performance factors
} 
In addition to researchers in financial economics, those in the fields of management and accounting have also explored the nature of relationship between managerial pay and performance. Most of the studies in this group have used accounting-based measures of performance, such as return on equity or return on assets. However, such measures may bear little resemblance with the economic return earned by the firm since they do not account for the capital costs incurred by the firm (and do depend on the choice of the accounting methods utilized). For example, consider the earnings growth which may follow a decision to increase the scale of the operations. It does not automatically follow that such growth will lead to a per-share value growth because the former may be achieved at excessive capital costs. Additionally, even those studies which utilize measures of performance that are based on market returns fail to adjust those returns for (the required rates of return given) their degrees of riskiness. The end result is that the exact relation between pay and performance can be somewhat different than what the extant empirical results may suggest.

This study is designed to further clarify the nature of the relationship between pay and performance. It investigates the relationship between executive compensation and two measures of firm performance with promise for acting as proxies for economic profits earned by the firm: Economic Value Added (EVA) and Market Value Added (MVA). EVA and MVA are terms coined by (and trademarks owned by) Stern Stewart and Co. However, the concept behind these terms is the net present value. Variations of this concept have been proposed by and utilized by other authors or consulting firms. ${ }^{2}$ EVA and MVA, however, have received wider attention both in the corporate world and in scholarly research (see for example, Hodak (1994), Lehn and Makhija (1996), Spinner (1995), Tully (1993), and Uyemura, Kantor, and Pettit (1996)). 
Suggested first by Stewart (1991), EVA can be thought of as a proxy for the measurement of economic returns. Simply stated, it is the firm's residual profitability in excess of capital costs. A firm's EVA is positive when after-tax operating profits exceed the dollar cost of capital. MVA is a closely related measure in that it can be thought of as the amount of cash that debt and equity investors can expect to get out of the firm beyond what they have contributed. These two performance measures are related because MVA is the present value of all expected future EVA, and can be thought of as the net present value of the firm.

Defined as they are, EVA and MVA are, therefore, reasonable proxies for the attainment of the owner wealth maximization goal. Nonetheless, the relationships between executive compensation and these measures of firm performance have not yet been explored empirically. In this study, we examine these relationships. Specifically, we examine the relationship between various forms of compensation and each of the two measures EVA and MVA. We believe that studying both sets of relationships can be quite instructive, despite the fact that MVA is removed by EVA simply by a present value operator. Consider, for example, the purchase of (or investment in) a real option with a (contingent) long-term payoff and an immediate cost. To the extent that the strategic positioning of the firm is improved, such an option will be valuable and will result in increased market value, perhaps at the expense of current period performance, both in accounting and economic terms.

We also examine whether compensation serves as a reward for past performance, or as an incentive for enhanced future performance. That is, given shareholder wealth maximization as the goal of the firm, is the existing executive compensation scheme used by public firms incentive-compatible? To answer this question, we use leading and lagged values of firm

\footnotetext{
${ }^{2}$ See, for example, Copeland, Koller and Murrin (1995) and Rappaport (1986).
} 
performance. If compensation is a reward for past performance, then it should be positively related to past values of performance measures. If, however, compensation is used as an incentive, we expect it to be positively related to leading measures of performance.

Further, we examine the relationship between compensation and two firm characteristics: size and risk. As hypothesized by Jensen and Meckling (1976), executive compensation, ownership structure and board composition are determined by each other and by the characteristics of a firm's business, including firm size. Further, the strategic management literature argues that compensation is likely related to firm size for several reasons. Greater size leads to more levels in the organizational hierarchy. Because pay differentials need to occur between levels, more levels lead to higher pay at the top (Mahoney, 1979). Economic theory of marginal revenue products also predicts greater pay in firms of greater size (Gomez-Mejia et al, 1987). Additionally, if an effective CEO can create greater profits for large firms than for small ones, then it is likely that the marginal productivity of the CEO would vary directly with size. Further, human capital theory predicts greater pay in firms of greater size (Becker, 1964). The prediction follows from the observation that the top position in a larger firm requires greater human capital because a larger firm is more complex, more difficult to manage and demands more responsibility than in a smaller firm. Finally, sociologists contend that pay is related to organizational power (Allen, 1981). Leaders of large organizations can be assumed to have generally greater power than those of small organizations, leading to greater pay.

Jensen and Meckling also hypothesize that compensation is related to the firm's risk. A simple explanation of this relation is that from an executive's perspective, the higher the risk of the firm, the greater the risk of his/her compensation. In an efficient managerial labor market, 
executives will demand, and receive, compensation for bearing risk, thus leading to a positive relationship between compensation and risk of the firm.

Executive compensation generally consists of several components such as salary, bonus, stock options, and long-term incentive payouts. It is plausible that certain components (such as bonuses) are used as a reward for past performance, while other components that are related to firm value are designed to provide the correct incentive for future performance. The complex design of the total compensation package requires that we separately examine the relationship between firm performance and each of these components.

The rest of the paper is organized as follows. In Section II, we describe the sample and the methodology. We present and discuss our results in Section III. Section IV concludes with a summary.

\section{Data and Methodology}

We define top managers as individuals with the title of Chairman, CEO, President and senior level Vice President. Compensation data are obtained from Standard and Poor's Corp. ExecuComp database. This database provides detailed annual executive compensation for about 1704 firms covering the period 1992-1996. In our study, we use four measures of compensation: salary, bonus, cash compensation, and total direct compensation. Cash compensation (CASHCOMP) is defined as the sum of salary (SALARY) and bonus (BONUS). Total Direct Compensation (TDC) is defined as the sum of salary, bonus, value of restricted stock granted, value of stock options granted, and other annual items. ${ }^{3}$

\footnotetext{
${ }^{3}$ Other annual compensation includes perquisites, payments to cover executive's taxes (gross-up), preferential earnings payable but deferred at executive's election, and preferential discounts of stock purchases.
} 
The number of executives varies across the firms in our sample, ranging from 1 to 12 . Larger firms tend to have a greater number of executives. Since we are interested in the total executive compensation package of the firm, for each firm (and for each year) in the sample period, we aggregate the compensation component for all executives of this firm listed in the Standard \& Poor's database. Implicit in this aggregation is the assumption that the firm's compensation policy applies uniformly to top executives of different ranks. Prior research has shown that this hierarchical assumption is reasonable (Demski and Sappington (1989) and Werner and Tosi (1995)). Data requirements for the incentive/reward hypothesis require us to use annual compensation in the four-year period from 1992 to 1995.

Firm performance measures such as EVA, MVA, and return on capital (ROC) are obtained from Stern Stewart \& Co.'s Performance 1000 Database. This database provides annual information on these profitability measures and other related firm specific attributes for 1,000 firms covering the period 1987-1995. The cost of capital (COC) and the total capital employed by the firm (CAPITAL) are also obtained from this database.

In combining the samples of firms obtained from the compensation and the performance databases, we require that data be available for all variables to be used in tests of our hypothesis. This results in a final sample size of 1965 observations, where each observation is a firm-year. The numbers of firms in each year from 1992 to 1995 are 432, 550, 502, and 481 respectively.

Since EVA, MVA, and compensation measures are measured in dollars and therefore related to firm size, we control for firm size differences in our cross-sectional tests. Firm size is measured by the capital employed at the beginning of the year (BOYCAP). Using this measure of firm size, SALARY is redefined as SALARY/BOYCAP. Other compensation measures are adjusted for firm size similarly. We also define the firm-size standardized EVA (denoted as 
SEVA) as EVA/BOYCAP. Since MVA is the total market value added to the stock of capital, it is a cumulative measure. The incremental market value added during year $t$, after adjustment for differences in firm sizes, is defined as

$$
\Delta \mathrm{MVA}_{\mathrm{t}}=\frac{\mathrm{MVA}_{\mathrm{t}}-\mathrm{MVA}_{\mathrm{t}-1}}{\mathrm{BOYCAP}_{\mathrm{t}}}
$$

Table 1 provides descriptive statistics for all variables used in our cross-sectional tests. On average, cash compensation (CASHCOMP) is about two-thirds of the total direct compensation (TDC) paid to executives in our sample. Further, the usual accounting measures of performance (ROA and ROE) are positive on average. However, the average return on total capital employed (ROC) is less than the average cost of capital (COC). By implication, therefore, the average EVA should be negative, given that EVA is defined as the product of the capital employed and difference between the return and the cost of capital [= CAPITAL x (ROC COC)]. In fact, the average EVA in our sample is about $-\$ 95.7$ million. Of the 1965 observations in our sample, 1,247 (63.5 percent) had a negative EVA.

\section{[Insert Table 1 here]}

It is tempting to conclude, on the basis of this negative average EVA, that our sample firms have been engaged in sub-optimal decision making with respect to resource allocation. However, the positive incremental market value added ( $\triangle \mathrm{MVA}$ ) suggests a different implication. For strategic reasons, firms may commit resources to investments with expected payoffs in the distant future. Investments in these real options are valuable and their value is reflected in a higher market value of the firm. Thus, even though the EVA is negative, the market views these investments favorably, and consequently revalues the firm upwards. Of the 1,247 firmobservations with negative EVA, 60.5 percent had positive increments to their market value, 
while the market value for the remaining 39.5 percent declined. Interestingly, this proportion of positive $\Delta$ MVA firms is comparable to the proportion of positive $\Delta$ MVA firms in the total sample (60.7 percent).

In Table 2 we provide simple correlation coefficients between the variables used in this study. Panel A reports correlation coefficients between our measure of firm size (CAPITAL) and the four compensation measures (unadjusted for firm size differences). All correlation coefficients are positive and significant at the one percent level. Thus, firm size is an important determinant of executive compensation with larger firms having larger compensation packages. [Insert Table 2 here]

In Panel B, we report the correlation coefficients between measures of performance and the compensation components. The positive correlation between cost of capital and compensation provides preliminary support for our hypothesis that risk bearing on the part of executives is compensated. Generally, there is a strong indication of a positive relation between firm performance and compensation. However, compensation is not related to ROE. On the other hand, the strong positive relation between compensation and ROA may suggest that compensation policy is more a function of "enterprise" performance rather than simple return to equityholders. With the exception of bonus, all other components of compensation show a stronger correlation with the market value added than they do with traditional measures of performance.

In Panel C, we report correlation coefficients between our measures of firm performance. While there is a statistically significant correlation between virtually all performance measures, the magnitude of these correlation coefficients is relatively small in all but three cases: ROA is highly positively correlated with both ROC and SEVA, and SEVA is highly correlated with 
ROC. This is not surprising since, by definition, these three variables are closely related to each other.

\section{Results}

\section{III.A Determinants of Executive Compensation}

We now conduct formal tests of our hypotheses about the determinants of executive compensation using a cross-sectional regression framework. The dependent variables in all our cross-sectional regressions are components of compensation. All models are estimated for the four components of compensation (SALARY, BONUS, CASHCOMP and TDC). For brevity, we refer to compensation components generically as COMP. In all regressions, the t-statistics are based on White's (1980) heteroskedasticity consistent estimators of the standard errors of the model's parameters.

The first hypothesis concerns the relation between firm size and compensation. We estimate the following model:

$$
\operatorname{COMP}_{\mathrm{i}}=\alpha_{0}+\alpha_{1} \mathrm{CAPITAL}_{\mathrm{i}}+\varepsilon_{\mathrm{i}}
$$

where $\mathrm{COMP}_{\mathrm{i}}$ is the compensation component of interest for firm $\mathrm{i}$, the $\alpha$ 's represent the model parameters and $\varepsilon_{\mathrm{i}}$ is the error term. The estimates of this model are shown in Table 3. All measures of compensation are significantly positively related to firm size, as measured by the total capital employed at the end of the year. Due to this strong positive relationship between firm size and compensation, we normalize all variables in subsequent tests for firm size. ${ }^{4}$ Failure

\footnotetext{
${ }^{4}$ Our normalization is done using capital employed at the beginning of the year. In Table 3, the capital is measured at the end of the year. However, when we regress compensation on beginning of year capital, the results of these regressions are indistinguishable from those reported in Table 3.
} 
to normalize for size would mask the true relationships between compensation and firm performance.

\section{[Insert Table 3 here]}

We also hypothesize a positive relationship between compensation and the risk of the firm. While equity beta coefficients are often used as a measure of risk, they only measure the risk borne by the shareholders. Since we are concerned with the overall riskiness of the firm, we need to incorporate the risk borne by other security holders in the firm as well. The weightedaverage cost of capital can therefore serve as a reasonable proxy for the firm's risk. Thus, to examine the relationship between compensation and risk, we estimate the following model:

$$
\mathrm{COMP}_{\mathrm{i}}=\alpha_{0}+\alpha_{1} \mathrm{COC}_{\mathrm{i}}+\varepsilon_{\mathrm{i}}
$$

The results of these estimations are presented in Table 4. All components of compensation are significantly positively related to the risk of the firm. This supports our hypothesis that the higher the risk of the firm, the greater will be the risk of executive compensation. In an efficient managerial labor market, executives will demand, and receive, compensation for bearing risk, thus leading to a positive relationship between compensation and risk of the firm.

\section{[Insert Table 4 here]}

The preceding results indicate that executive compensation is significantly and positively related to both firm size and risk. Thus, in examining the pay-for-performance relationships, we must control for differences in firm size and risk across the firms in the sample. The adjustment for firm size is relatively straightforward - the compensation variables can be normalized by a measure of firm size. To control for risk, we can include our proxy for risk (the cost of capital) as an independent explanatory variable. However, from Panel C of Table 2, the cost of capital is 
positively related to all measures of firm performance. In particular, there is a relatively high correlation between the cost of capital and ROA, ROC, and SEVA. This could lead to problems of multi-collinearity in the independent variables, masking the nature of the underlying relationship between pay and performance. Accordingly, we estimate the relationship between compensation and firm performance in two iterations: once excluding the cost of capital as an independent variable and once including it.

In Table 5, we report parameter estimates for the following model:

$$
\mathrm{COMP}_{\mathrm{i}}=\alpha_{0}+\alpha_{1} \mathrm{PERF}_{\mathrm{i}}+\varepsilon_{\mathrm{i}}
$$

where the performance measure PERF is either ROC, $\triangle \mathrm{MVA}$, SEVA, ROA or ROE. In Table 6, we report the estimates of the model including $\mathrm{COC}$ as the measure of risk:

$$
\mathrm{COMP}_{\mathrm{i}}=\alpha_{0}+\alpha_{1} \mathrm{PERF}_{\mathrm{i}}+\alpha_{2} \mathrm{COC}_{\mathrm{i}}+\varepsilon_{\mathrm{i}}
$$

The results reported in Tables 5 and 6 indicate that all measures of compensation are significantly positively related to the return on capital, return on assets and market value added. Only two measures of compensation, bonus and total direct compensation, are marginally positively related to the economic value added. Furthermore, the parameter estimates and significance levels are, in general, similar in both Tables 5 and 6. Therefore, it appears that multi-collinearity among the independent variables does not pose a significant problem in these models.

[Insert Table 5 here]

[Insert Table 6 here]

These results provide strong evidence in support of the hypothesis that executive compensation is related to the market value added. However, there is only weak evidence in support of the presence of a relationship between compensation and economic value added. 
While salary is unrelated to EVA, bonus and other non-salary components of compensation are positively related to EVA, albeit at lower significance levels.

A number of previous studies have documented the presence of a significant positive relationship between executive compensation and return on assets (e.g., see Pavlik and Belkaoui, (1991)). Although EVA and MVA, are measures of performance more indicative of contribution to shareholder wealth, it is not clear whether these broader measures are better predictors of the cross-sectional variation in executive compensation. To investigate this issue, we estimate the following model:

$$
\mathrm{COMP}_{\mathrm{i}}=\alpha_{0}+\alpha_{1} \mathrm{COC}_{\mathrm{i}}+\alpha_{2} \mathrm{ROA}_{\mathrm{i}}+\alpha_{3} \mathrm{PERF}_{\mathrm{i}}+\varepsilon_{\mathrm{i}}
$$

where PERF is either ROC, SEVA, or $\triangle \mathrm{MVA}$.

The estimates of this model are presented in Table 7. With PERF defined as $\triangle \mathrm{MVA}$, and for all components of compensation, the coefficients of COC, ROA, and $\triangle \mathrm{MVA}$ are positive and significant at the one percent level. Moreover, the adjusted $\mathrm{R}^{2}$ values fall in the range 0.09 to 0.13. When only COC and ROA are used as independent variables, the adjusted $\mathrm{R}^{2}$ values are in the range 0.05 to 0.09 (see Panel E, Table 6). Thus, it can be concluded that MVA is, indeed, a significant predictor of cross-sectional variations in executive compensation.

[Insert Table 7 here]

In the second and third panels of Table 7, PERF is defined as SEVA and ROC respectively. However, by including these variables, the explanatory power of ROA is virtually eliminated. We suspect that this is due to the high correlation between ROA and ROC $(\rho=0.76)$ and also between ROA and SEVA $(\rho=0.66)$. The high degree of multi-collinearity makes interpretation of the significance levels of the model's parameters difficult. In the last panel of 
Table 7, performance is defined to encompass ROA, EVA and MVA. The results indicate that while MVA is a significant variable neither of the other two are.

\section{III.B Compensation and Strategic Decision Making}

The evidence presented above indicates that executive compensation is positively related to the market value added and, somewhat less pronounced, to the economic value added. Since MVA is the present value of future expected EVA, and since the relationship between MVA and compensation is strong, why then is the relationship between compensation and EVA weaker? To explore this issue further, we sort the total sample into groups based on SEVA and $\triangle \mathrm{MVA}$.

All firms in the sample are ranked independently based on these two variables. The sample is then divided into three groups of equal size based on SEVA values. A similar partitioning of the sample into three equal-sized groups is carried out using $\triangle \mathrm{MVA}$ values. Combinations of rankings based on SEVA and $\triangle$ MVA thus yields nine sub-samples. We then analyze the following four sub-samples further: high SEVA / high $\triangle \mathrm{MVA}$; high SEVA / low $\triangle \mathrm{MVA}$; low SEVA / high $\triangle \mathrm{MVA}$; and low SEVA / low $\triangle \mathrm{MVA}$. We denote these four subsamples as $\mathrm{HH} ; \mathrm{HL} ; \mathrm{LH}$ and LL respectively. ${ }^{5}$

We view these four sub-samples in the following manner. The HH sub-sample consists of firms that generate high economic returns with a high market value; firms which may be positioned to enjoy a prolonged period of economic rents. The HL sub-sample firms generate high economic return with a relative low market value; firms with limited growth prospects and low expected economic profits. ${ }^{6}$ The LL sub-sample represents firms whose current and future

\footnotetext{
5 The first letter in the sub-sample designation refers to the SEVA ranking, while the second letter refers to the $\triangle$ MVA ranking.

6 An alternative interpretation is that these firms these firms are "window dressing" their current income.
} 
ability to generate economic profits is severely limited. Finally, the LH sub-sample represents firms with low current profits making investments in valuable real options.

Table 8 provides descriptive statistics on the components of executive compensation for these four sub-samples. Compensation variables have been normalized by beginning-of-year capital to account for firm size differences. The most striking result from this table is the difference in compensation levels between the HH and LL sub-samples. For example, the average salary of executives in the HH sub-sample is 0.74 , while that for executives in the LL sub-sample is 0.32 . Similar differences are observed for all other components of salary. All of the differences in compensation between these two sub-samples are significant at the 1 percent level.

\section{[Insert Table 8 here]}

These differences in compensation levels suggests that, on average, the compensation policy of these firms is rational: executives that generate high economic and market value for the firm are compensated significantly higher than executives that do not.

We next examine the relationship between compensation and EVA and MVA for each of the four sub-samples. The first four panels of Table 9 report our estimates of the model in equation (5) using SEVA as the measure of firm performance. The next four panels contain the results when $\triangle \mathrm{MVA}$ is used as the measure of performance. Results reported in the first two panels, the HH and HL sub-samples, indicate that the estimates of the coefficients on SEVA are positive and generally significant. Thus, for firms that generate high economic profits EVA is a significant determinant of compensation.

[Insert Table 9 here] 
The next panel contains results of the regressions for the low SEVA/high $\triangle \mathrm{MVA}$ subsample, i.e. firms making large investments in valuable options with long-term payoffs. For these managers, compensation is negatively correlated with EVA. The estimates of the coefficients on SEVA are all negative and significantly so. It appears that foregoing these opportunities in the interest of reporting higher current period income has a compensation penalty attached to it. Moreover, the adjusted $\mathrm{R}^{2}$ values are the highest of all for sub-sample regressions, ranging between 0.30 and 0.47 . Our results for the LL sub-sample, reported in the fourth panel of Table 9, further indicate that SEVA is not a significant determinant of pay for firms limited current or future growth possibilities.

The next set of four panels report the estimates of equation (5) where $\Delta \mathrm{MVA}$ is used as a measure of performance. The results indicate that this measure of performance is, in general, positively correlated with compensation, especially for the sub-samples where the market value added is above average.

A similar pattern emerges when we include both SEVA and $\triangle \mathrm{MVA}$ as performance measures for the firm. In Table 10, we report the results of the estimation of the model with both explanatory variables (along with a control for risk differences). ${ }^{7}$ MVA emerges as a significant determinant of compensation in all but the high SEVA/low $\triangle$ MVA sub-sample. Further, in the sub-sample where EVA is below average but MVA is above average, the results are similar to those presented in Table 9. The estimates of the coefficients on $\triangle \mathrm{MVA}$ are all significantly positive, while those on SEVA are all significantly negative, i.e., higher SEVA brings in a compensation penalty but higher $\triangle \mathrm{MVA}$ is rewarded (Further, the adjusted $\mathrm{R}^{2}$ values are the

\footnotetext{
7 The correlation between SEVA and $\triangle$ MVA reported in Table 2 is judged to be not high enough to lead to problems associated with multicollinearity between these two independent variables.
} 
highest of all four sub-samples.) These results therefore run counter to the argument that managers are rewarded for myopic behavior. Rather, they are consistent with the argument that executive compensation is closely linked to shareholder value creation.

[Insert Table 10 here]

Taken together, the results presented in Tables 8 through 10 indicate executive compensation levels are related to the level of EVA and MVA generated by the firm. Moreover, both EVA and MVA as measures of firm performance help explain the cross-sectional variation of compensation within and across sub-samples formed on the basis of the levels of EVA and MVA generated. In all cases, except for the high SEVA/low $\triangle$ MVA sub-sample, compensation is significantly positively related to $\Delta$ MVA. More importantly, when market value added is high, compensation can be a negative function of EVA. This negative relationship suggests that for firms with valuable growth options, those managers that create value through these options are compensated in proportion to the value created. Those managers that forego the opportunities in favor of improving current-period EVA are penalized.

\section{C. Compensation and the Reward/Incentive Hypothesis}

Finally, we test whether compensation is used by firms as a reward for managerial effort based on superior past performance or as an incentive for improved future firm performance. These tests are conducted using lagged and leading values of firm performance. If compensation rewards managers for superior performance in the current period only, then neither the lagged nor the leading values of firm performance would be significant in explaining current period compensation. If compensation rewards managers for prior superior performance, then only the lagged performance variables would be significant. Conversely, if compensation is used to 
motivate managers to improve performance in the future, only the leading values of performance would be significant.

We regress compensation on two lagged and two leading values of SEVA and $\triangle \mathrm{MVA}$, after controlling for differences in firm risk. Since a total of five years of firm performance is required to test this hypothesis, the sample size is reduced to 1871 observations. We use the compensation data from two years (1992 and 1993). Thus, year 0 is defined as one of these two years and lagged and leading measures of performance are measured relative to this base year. We estimate the following model:

$$
\begin{aligned}
\operatorname{COMP}_{\mathrm{i}, \mathrm{t}}=\alpha_{0} & +\alpha_{1} \mathrm{COC}_{\mathrm{i}, \mathrm{t}}+\alpha_{2} \mathrm{PERF}_{\mathrm{i}, \mathrm{t}-2}+\alpha_{3} \mathrm{PERF}_{\mathrm{i}, \mathrm{t}-1} \\
& +\alpha_{4} \mathrm{PERF}_{\mathrm{i}, 0}+\alpha_{5} \mathrm{PERF}_{\mathrm{i}, \mathrm{t}+1}+\alpha_{6} \mathrm{PERF}_{\mathrm{i}, \mathrm{t}+2}+\varepsilon_{\mathrm{i}}
\end{aligned}
$$

Table 11 presents the estimates of this model's parameters using SEVA as the measure of firm performance. The estimates of the coefficients on contemporaneous and lagged values of $\operatorname{SEVA}\left(\alpha_{2}, \alpha_{3}\right.$, and $\alpha_{4}$ in equation (7) above) are insignificantly different from zero. Thus, at least when firm performance is measured by SEVA, there is no evidence to support that compensation rewards managers for past or current performance. However, the results reported in Table 11 provide limited support for the incentive pay hypothesis. The estimates for the cash components of compensation based on year $t+1$ are significantly positive. Moreover, the estimate of $\alpha_{6}($ year $t+2)$ is also significantly greater than zero for total compensation, but not for cash components of compensation. This pattern in the direction and significance of the leading coefficients suggests that bonus and total compensation can be viewed as managerial incentives for improved future firm performance.

[Insert Table 11 here] 
In Table 12, we present the estimates of the model in equation (7) above, using $\triangle \mathrm{MVA}$ as the measure of firm performance. The evidence supports the reward hypothesis for cash components of compensation: the estimates of the coefficients on $\Delta \mathrm{MVA}_{\mathrm{t}-2}$ and $\Delta \mathrm{MVA}_{0}$ are all positive and significant. Moreover, there is also evidence to support the incentive hypothesis in the case of non-cash components of compensation. When we regress total direct compensation (TDC) on firm performance, the coefficient on $\Delta \mathrm{MVA}_{\mathrm{t}+2}$ is positive and significant, but it is not significant in the regressions of the cash components of compensation. The significance of the coefficient in the TDC regression is driven by the non-cash components of compensation. This makes sense, since the non-cash component includes stock options granted to executives. The value of these options increases with the market value of the firm, resulting in higher executive compensation.

\section{[Insert Table 12 here]}

Taken together, our results suggest that executives are rewarded for their efforts to create economic and market value for the firm. Further, their compensation also acts as an incentive for creating additional market value in the future.

\section{Conclusions}

In this paper, we examine the relationship between executive compensation and measures of performance capturing the economic profit earned by the firm. We also investigate the causal direction between the wealth creation activities of the firm and the compensation of its top managers. The effectiveness of executives in wealth creation is proxied by two widely-used measures: Economic value added (EVA) and market value added (MVA). EVA and MVA purport tapping value creation based on the effective management of resources rather than 
profits. We hypothesize that, after controlling for size and risk, these measures are significant determinants of executive compensation. Consistent with prior studies examining top manager compensation, we desegregate the compensation package of top managers into cash, merit pay (bonus) and total direct compensation, which includes long-term incentives such as stock options.

Consistent with the extant evidence, we find that executive compensation is related to both the size and the riskiness of the firm. Further, we find support for our hypothesis that the market value added to the firm is a significant determinant of executive pay. Comparing traditional measures of firm performance and MVA, we find that including the market value added to the firm in assessing executive compensation provides additional information about the nature of top manager pay. In general, we find that EVA and MVA are better predictors of crosssectional variation in top manager pay than traditional performance measures such as return on assets (ROA).

Perhaps one of the most significant findings of our study is arrived at when we divide our sample firms into four groups based on their rankings of market and economic value added. By grouping firms into cohorts based on polar performance (high/low) for each of the two performance measures, we are able to identify four distinct groups which may be referred to as "winners" (high MVA and EVA), "losers" (low MVA and EVA), "holders of real options" (high MVA/low EVA) and "problem children" (Low MVA/high EVA). Our findings suggest that market value added and economic value added are both significant determinants of executive pay. However, where EVA may be achieved at the expense of MVA (i.e., the problem children group) such behavior brings in a compensation penalty. Accordingly, it can be inferred that compensation contracts are, generally, set in a manner which encourages the managers to act in 
the long-term interest of the shareholders even when doing so may mean lower short-term profits.

Finally, we assess whether top manager pay is an incentive for future performance or reward for past behavior. Our evidence suggests that top managers are incented to increase the EVA of the firm but are also rewarded for past additions the market value as measured by MVA.

We also assess the causal direction of the pay for performance relationship. We demonstrate that achieving superior wealth creation for owners is accomplished by linking top manager pay to the economic value created in the current period and by the ability of managers to signal the marketplace about the progress (real options) being created by the firm for future periods. Thus, our study indicates that the best wealth creating top managers are responsible for multi-dimensional behavior of the firm--EVA additions today as well as in the future (and hence MVA).

There are two implications for future research. First, future research should consider including additional information regarding analysts' estimates of future earnings as a measure of future MVA performance. This would help clarify whether the performance of "winners" is expected by the marketplace or executives are rewarded for performance "surprises." In addition, extending our work to the international environment is recommended. This would help assess the validity the relationships reported in our study cross-nationally thus determining if compensation plans for international managers can be structured as domestic managers. 


\section{References}

Agarwal, N. 1981. Determinants of executive compensation. Industrial Relations. 20(1): 36-45.

Allen, M.P. 1981. Power and privilege in large corporation: Corporate control and managerial compensation. American Journal of Sociology, 86(5): 1112-1123.

Becker, G.S. 1964 Human Capital, New York: National Bureau for Economic Research.

Copeland, T., T. Koller, and J. Murrin. 1995. Valuation: Measuring and managing the value of companies. New York: John Wiley \& Sons.

Deckop, J. R. 1988. Determinants of chief executive officer compensation. Industrial and Labor Relations Review. 41(2): 215-226.

Demski, J. S. and D. E. Sappington. 1989. Hierarchical structure and responsibility accounting. Journal of Accounting Research. 27(1): 40-58.

Gomez-Mejia, L., H. Tosi and T. Hinkin. 1987. Managerial control, performance and executive compensation. Academy of Management Journal. 30(1): 51-70.

Grosman, S.J. and O.D. Hart. 1983. An analysis of the principal agent problem. Econometrica. 51: 7-45.

Hadlock, C.J. and G.B. Lumer. 1997. Compensation, turnover, and top management incentives: Historical evidence. Journal of Business. 70(2); 153-187.

Harris, M. and A. Raviv. 1979. Optimal incentive contracts with imperfect information. Journal of Economic Theory. 20: 231-259.

Hodak, M. 1994. How EVA can help turn mid-sized firms into large companies. Journal of Applied Corporate Finance: 98-102

Jensen, M. C. and W. H. Meckling. 1976. Theory of the firm: Managerial Behavior, Agency costs and ownership structure. Journal of Financial Economics. 3(4): 305-360.

Jensen, M. and K. Murphy. 1990. Performance pay and top-management incentives. Journal of Political Economy. 98(2): 225-64.

Kroll, M., S. Simmons and P. Wright. 1990. Determinants of CEO compensation following major acquisitions. Journal of Business Research. 20: 349-66.

Lehn, K. and A. Makhija. 1996. EVA and MVA as performance measures and signals for strategic change. Strategy and Leadership. May/June: 34-38 
Leonard, J.S. 1990. Executive pay and firm performance. Industrial and Labor Relations Review. 43: 13-29.

Mehran, H. 1995. Executive Compensation structure, ownership and firm performance. Journal of financial Economics. 38(2): 163-184.

Mahoney, T.A. 1979. Organizational hierarchy and position worth. Academy of Management Journal, 22: 726-737.

Murphy, K.J. 1985. Corporate performance and managerial remuneration: An empirical analysis. Journal of Accounting and Economics 7: 11-42.

Pavlik, E.L, and A. Belkaoui. 1991. Determinants of Executive Compensation. Westport, CT: Quorum Books.

Rappaport, A. 1986. Creating Shareholder Value: The New Standard for Business Performance. New York: Free Press.

Spinner, K. 1995. Signed and sealed - But can EVA deliver? CFO Magazine. November: 9395.

Stewart, G. 1991. The Quest for Value: A Guide for Senior Managers. New York, NY: HarperCollins.

Tosi, H., Werner, S., J. Katz, and L. Gomez-Mejia. 1997. Determinants of CEO pay: A metaanalytic study. Working paper, University of Florida, Gainesville, FL

Tully, S. 1993. The real key to creating value. Fortune. September: 38-44.

Uyemura, D.G., C. C. Kantor and J. M. Pettit. 1996. EVA for banks: value creation, risk management, and profitability management. Journal of Applied Corporate Finance. Summer: 94-113.

Werner, S. and H. L. Tosi. 1995. The effect of ownership on compensation strategy and managerial pay. Academy of Management Journal. 38(6): 1672-1691.

White, H. 1980. A heteroskedasticity-consistent covariance matrix estimator and a direst test for heteroskedasticity. Econometrica, 48: 817-838.

Winn, D. and J. D. Shoenhair 1988. Compensation-based (dis)incentives for revenuemaximizing behavior: A test of the revised Baumol Hypothesis. Review of Economics and Statistics. 154-158. 


\section{Table 1}

Descriptive Statistics on Measures of Compensation, Risk, and Firm Performance for the Sample of 1965 Observations between 1992 and 1995.

\begin{tabular}{lcc}
\hline Variable & Mean & $\begin{array}{c}\text { Standard } \\
\text { Deviation }\end{array}$ \\
\hline SALARY $^{1}$ & 409.385 & 216.461 \\
BONUS $^{1}$ & 272.482 & 333.467 \\
CASHCOMP $^{1}$ & 681.867 & 467.690 \\
TDC $^{1}$ & 1609.38 & 3311.88 \\
{$\left[\begin{array}{lc}\text { CASHCOMP } \\
\multicolumn{1}{c}{\text { TDC }}\end{array}\right]^{3}$} & 61.626 & 23.033 \\
CAPITAL & & \\
COC $^{3}$ & 4736.95 & 10323.29 \\
BETA $^{2}$ & 11.684 & 2.333 \\
ROE $^{3}$ & 1.064 & 0.507 \\
ROA $^{3}$ & 12.767 & 86.124 \\
ROC3 $^{3}$ & 5.130 & 7.478 \\
EVA $^{2}$ & 10.947 & 8.901 \\
MVA $^{2}$ & -95.742 & 652.402 \\
SEVA $^{3}$ & 3599.90 & 9028.39 \\
$\Delta$ MVA $^{3}$ & -0.650 & 9.198 \\
\hline
\end{tabular}

\footnotetext{
${ }^{1}$ In thousands of dollars

${ }^{2}$ In millions of dollars

${ }^{3}$ In percent
} 


\section{Table 2}

Correlation Coefficients Between Selected Measures of Compensation and Firm Size, Risk and Performance for the Sample of 1965 Observations between 1992 and 1995. ${ }^{1}$

Panel A

\begin{tabular}{l|rrrr}
\cline { 2 - 4 } & \multicolumn{1}{c}{ SALARY } & BONUS & CASHCOMP & TDC \\
\hline CAPITAL & $0.436 * * *$ & $0.252 * * *$ & $0.382 * * *$ & $0.295 * * *$ \\
\hline
\end{tabular}

Panel B

\begin{tabular}{l|llll}
\hline COC & $0.211 * * *$ & $0.250 * * *$ & $0.248 * * *$ & $0.224 * * *$ \\
ROA & $0.132 * * *$ & $0.258 * * *$ & $0.202 * * *$ & $0.156 * * *$ \\
ROE & 0.012 & 0.030 & 0.021 & 0.015 \\
ROC & $0.139 * * *$ & $0.272 * * *$ & $0.214 * * *$ & $0.181 * * *$ \\
SEVA & 0.118 & $0.193 * * *$ & $0.101 * * *$ & $0.101 * * *$ \\
$\Delta \mathrm{MVA}$ & $0.235 * * *$ & $0.228 * * *$ & $0.253 * * *$ & $0.300 * * *$ \\
\hline
\end{tabular}

Panel C

\begin{tabular}{l|rrrrr}
\cline { 2 - 6 } & ROA & ROE & ROC & SEVA & \multicolumn{1}{c}{$\Delta \mathrm{MVA}$} \\
\cline { 2 - 6 } COC & $0.421 * * *$ & $0.049 * *$ & $0.477 * * *$ & $0.225 * * *$ & $0.108 * * *$ \\
ROA & & $0.138 * * *$ & $0.761 * * *$ & $0.663 * * *$ & $0.075 * * *$ \\
ROE & & & $0.140 * * *$ & $0.125 * * *$ & -0.015 \\
ROC & & & & $0.928 * * *$ & $0.225 * * *$ \\
SEVA & & & & & $0.313 * * *$ \\
\hline
\end{tabular}

${ }^{1}$ Compensation variables used to compute the correlation coefficients with CAPITAL are not adjusted for differences in firm size. In all other computations in the table, compensation variables are scaled by the capital employed at the beginning of the year. ***, **, and * indicate significance at the $1 \%, 5 \%$, and $10 \%$ levels respectively. 


\section{Table 3}

Ordinary Least Squares Regression Estimates of the Model Relating Compensation to Firm Size, for the Sample of 1965 Observations between 1992 and 1995. ${ }^{1}$

Model: $\quad \operatorname{COMP}_{\mathrm{i}}=\alpha_{0}+\alpha_{1} \mathrm{CAPITAL}_{\mathrm{i}}+\varepsilon_{\mathrm{i}}$

where $\mathrm{COMP}_{\mathrm{i}}$ is the component of executive compensation, and CAPITAL $\mathrm{L}_{\mathrm{i}}$ is the total capital employed by the firm.

\begin{tabular}{lcccc}
\hline $\begin{array}{c}\text { Compensation } \\
\text { Measure }\end{array}$ & $\alpha_{0}$ & $\alpha_{1}$ & $\begin{array}{c}\text { F-Statistic } \\
\text { (p-value) }\end{array}$ & Adjusted $^{2}$ \\
SALARY & $\begin{array}{l}366.089 * * * \\
(74.34)\end{array}$ & $\begin{array}{c}0.009^{* * *} \\
(12.43)\end{array}$ & $\begin{array}{c}460.49 \\
(<0.01)\end{array}$ & 0.19 \\
& & & & \\
BONUS & $233.905^{* * *}$ & $0.008^{* * *}$ & 133.24 & 0.06 \\
& $(29.08)$ & $(6.64)$ & $(<0.01)$ & \\
CASHCOMP & $599.994 * * *$ & $0.017 * * *$ & 334.38 & 0.15 \\
& $(54.87)$ & $(10.31)$ & $(<0.01)$ & \\
TDC & $1,479.968^{* * *}$ & $0.027 * * *$ & 14.34 & 0.01 \\
& $(18.06)$ & $(3.79)$ & $(<0.01)$ & \\
\hline
\end{tabular}

${ }^{1} \mathrm{t}$-statistics are in parenthesis. ${ }^{* *}, * *$, and $*$ indicate significance at the $1 \%, 5 \%$, and $10 \%$ levels respectively. 


\section{Table 4}

Ordinary Least Squares Regression Estimates of the Model Relating Compensation Measures to Firm Risk, for the Sample of 1965 Observations between 1992 and $1995 .{ }^{1}$

Model: $\quad \operatorname{COMP}_{\mathrm{i}}=\alpha_{0}+\alpha_{1} \mathrm{COC}_{\mathrm{i}}+\varepsilon_{\mathrm{i}}$

where $\mathrm{COMP}_{\mathrm{i}}$ is the component of executive compensation, and $\mathrm{COC}_{\mathrm{i}}$ is the cost of capital of the firm.

\begin{tabular}{lcccc}
\hline $\begin{array}{c}\text { Compensation } \\
\text { Measure }\end{array}$ & $\alpha_{0}$ & $\alpha_{1}$ & $\begin{array}{c}\text { F-Statistic } \\
(\mathrm{p} \text {-value })\end{array}$ & Adjusted $\mathrm{R}^{2}$ \\
SALARY & $\begin{array}{c}0.461^{* * *} \\
(-5.27)\end{array}$ & $\begin{array}{c}0.075^{* * *} \\
(9.04)\end{array}$ & $\begin{array}{c}91.18 \\
(<0.01)\end{array}$ & 0.04 \\
& $-0.512^{* * *}$ & $0.066^{* * *}$ & 130.86 & 0.06 \\
BONUS & $(-7.19)$ & $(9.56)$ & $(<0.01)$ & \\
& $-0.973^{* * *}$ & $0.140^{* * *}$ & 128.90 & 0.06 \\
CASHCOMP & $(-6.82)$ & $(10.30)$ & $(<0.01)$ & \\
& & & & \\
TDC & $-6.908^{* * *}$ & $0.756 * * *$ & 124.16 & 0.06 \\
& $(-5.71)$ & $(6.58)$ & $(<0.01)$ & \\
\hline
\end{tabular}

${ }^{1}$ t-statistics are in parenthesis. ${ }^{* *}, * *$, and $*$ indicate significance at the $1 \%, 5 \%$, and $10 \%$ levels respectively. 


\section{Table 5}

OLS Estimates of the Relation Between Compensation and Firm Performance, for the Sample of 1965 Observations Between 1992 and $1995 .{ }^{1}$

\begin{tabular}{|c|c|c|c|c|}
\hline $\begin{array}{c}\text { Compensation } \\
\text { Measure }\end{array}$ & $\alpha_{0}$ & $\alpha_{1}$ & $\begin{array}{c}\text { F-Statistic } \\
\text { (p-value) }\end{array}$ & Adjusted $\mathrm{R}^{2}$ \\
\hline \multicolumn{5}{|c|}{ Panel A: $\mathrm{COMP}_{\mathrm{i}}=\alpha_{0}+\alpha_{1} \mathrm{ROC}_{\mathrm{i}}+\varepsilon_{\mathrm{i}}$} \\
\hline SALARY & $\begin{array}{l}0.271 * * * \\
(5.27)\end{array}$ & $\begin{array}{l}1.295^{* * * *} \\
(3.45)\end{array}$ & $\begin{array}{c}38.80 \\
(<0.01)\end{array}$ & 0.02 \\
\hline BONUS & $\begin{array}{l}0.050^{*} \\
(1.65)\end{array}$ & $\begin{array}{l}1.871^{* * *} \\
(6.21)\end{array}$ & $\begin{array}{l}156.77 \\
(<0.01)\end{array}$ & 0.07 \\
\hline CASHCOMP & $\begin{array}{l}0.321 * * * \\
(4.14)\end{array}$ & $\begin{array}{l}3.166^{* * * *} \\
(5.08)\end{array}$ & $\begin{array}{r}9.382 \\
(<0.01)\end{array}$ & 0.06 \\
\hline TDC & $\begin{array}{r}-0.311 \\
(-1.24) \\
\end{array}$ & $\begin{array}{l}20.449 * * * \\
(11.52) \\
\end{array}$ & $\begin{array}{l}132.65 \\
(<0.01) \\
\end{array}$ & 0.06 \\
\hline \multicolumn{5}{|c|}{ Panel B: $\mathrm{COMP}_{\mathrm{i}}=\alpha_{0}+\alpha_{1} \Delta \mathrm{MVA}_{\mathrm{i}}+\varepsilon_{\mathrm{I}}$} \\
\hline SALARY & $\begin{array}{l}0.377 * * * \\
(27.32)\end{array}$ & $\begin{array}{l}0.001^{* * *} \\
(4.01)\end{array}$ & $\begin{array}{l}115.09 \\
(<0.01)\end{array}$ & 0.05 \\
\hline BONUS & $\begin{array}{l}0.229 * * * \\
(20.21)\end{array}$ & $\begin{array}{l}0.001^{* * * *} \\
(3.36)\end{array}$ & $\begin{array}{l}107.6 \\
(<0.01)\end{array}$ & 0.05 \\
\hline CASHCOMP & $\begin{array}{l}0.606^{* * * *} \\
(26.55)\end{array}$ & $\begin{array}{l}0.002 * * * \\
(4.31)\end{array}$ & $\begin{array}{l}134.54 \\
(<0.01)\end{array}$ & 0.06 \\
\hline TDC & $\begin{array}{l}1.535^{* * * *} \\
(9.68)\end{array}$ & $\begin{array}{c}0.013 * * * \\
(13.76) \\
\end{array}$ & $\begin{array}{l}189.22 \\
(<0.01) \\
\end{array}$ & 0.09 \\
\hline \multicolumn{5}{|c|}{ Panel C: $\mathrm{COMP}_{\mathrm{i}}=\alpha_{0}+\alpha_{1} \mathrm{SEVA}_{\mathrm{i}}+\varepsilon_{\mathrm{I}}$} \\
\hline SALARY & $\begin{array}{l}0.414 * * * \\
(27.03)\end{array}$ & $\begin{array}{c}0.002 \\
(.16)\end{array}$ & $\begin{array}{l}0.67 \\
(.41)\end{array}$ & 0.00 \\
\hline BONUS & $\begin{array}{l}0.263^{* * *} \\
(18.99)\end{array}$ & $\begin{array}{l}0.013^{* *} \\
(2.42)\end{array}$ & $\begin{array}{c}75.35 \\
(<0.01)\end{array}$ & 0.04 \\
\hline CASHCOMP & $\begin{array}{l}0.677 * * * \\
(25.77)\end{array}$ & $\begin{array}{c}0.014 \\
(.96)\end{array}$ & $\begin{array}{c}20.16 \\
(<0.01)\end{array}$ & 0.01 \\
\hline TDC & $\begin{array}{l}2.034 * * * \\
(12.71) \\
\end{array}$ & $\begin{array}{l}0.164 * * * \\
(9.42) \\
\end{array}$ & $\begin{array}{c}88.72 \\
(<0.01) \\
\end{array}$ & 0.04 \\
\hline
\end{tabular}


Table 5 (continued)

OLS Estimates of the Relation Between Compensation and Firm Performance, for the Sample of 1965 Observations Between 1992 and $1995 .{ }^{1}$

\begin{tabular}{|c|c|c|c|c|}
\hline $\begin{array}{c}\text { Compensation } \\
\text { Measure }\end{array}$ & $\alpha_{0}$ & $\alpha_{1}$ & $\begin{array}{c}\text { F-Statistic } \\
\text { (p-value) }\end{array}$ & Adjusted $\mathrm{R}^{2}$ \\
\hline \multicolumn{5}{|c|}{ Panel D: $\mathrm{COMP}_{\mathrm{i}}=\alpha_{0}+\alpha_{1} \mathrm{ROE}_{\mathrm{i}}+\varepsilon_{\mathrm{i}}$} \\
\hline SALARY & $\begin{array}{l}0.411^{* * *} \\
(21.77)^{2}\end{array}$ & $\begin{array}{l}0.011 \\
(.52)\end{array}$ & $\begin{array}{l}0.27 \\
(.60)\end{array}$ & 0.00 \\
\hline BONUS & $\begin{array}{l}0.252^{* * * *} \\
(18.31)\end{array}$ & $\begin{array}{c}0.021 \\
(1.17)\end{array}$ & $\begin{array}{l}1.78 \\
(.18)\end{array}$ & 0.00 \\
\hline CASHCOMP & $\begin{array}{l}0.663 * * * \\
(22.27)\end{array}$ & $\begin{array}{c}0.033 \\
(1.10)\end{array}$ & $\begin{array}{l}0.89 \\
(.34)\end{array}$ & 0.00 \\
\hline TDC & $\begin{array}{l}1.908^{* * *} \\
(11.84)\end{array}$ & $\begin{array}{c}0.156 \\
(1.06) \\
\end{array}$ & $\begin{array}{l}0.68 \\
(.41) \\
\end{array}$ & 0.00 \\
\hline \multicolumn{5}{|c|}{ Panel E: $\mathrm{COMP}_{\mathrm{i}}=\alpha_{0}+\alpha_{1} \mathrm{ROA}_{\mathrm{i}}+\varepsilon_{\mathrm{I}}$} \\
\hline SALARY & $\begin{array}{l}0.338^{* * * *} \\
(17.48)\end{array}$ & $\begin{array}{l}1.460 * * * \\
(6.80)\end{array}$ & $\begin{array}{c}34.74 \\
(<0.01)\end{array}$ & 0.02 \\
\hline BONUS & $\begin{array}{l}0.147 \text { *** } \\
(9.70)\end{array}$ & $\begin{array}{l}2.11 \text { *** } \\
(6.42)\end{array}$ & $\begin{array}{l}139.64 * * * \\
(<0.01)\end{array}$ & 0.07 \\
\hline CASHCOMP & $\begin{array}{l}0.484 * * * \\
(15.28)\end{array}$ & $\begin{array}{l}3.57 * * * \\
(7.00)\end{array}$ & $\begin{array}{c}83.81 \\
(<0.01)\end{array}$ & 0.04 \\
\hline TDC & $\begin{array}{l}0.880 \text { *** } \\
(5.92)\end{array}$ & $\begin{array}{l}20.425 * * * \\
(5.08)\end{array}$ & $\begin{array}{c}91.587 \\
(<0.01)\end{array}$ & 0.04 \\
\hline
\end{tabular}

${ }^{1} \mathrm{COMP}_{\mathrm{i}}$ is the measure of executive compensation, $\mathrm{ROC}_{\mathrm{i}}$ is the return on total capital, $\Delta \mathrm{MVA}_{\mathrm{i}}$ is the change in market value added, $\mathrm{SEVA}_{\mathrm{i}}$ is the standardized economic value added, $\mathrm{ROE}_{\mathrm{i}}$ is the return on equity, and $\mathrm{ROA}_{\mathrm{i}}$ is the return on assets for firm i. t-statistics are in parenthesis. $* * *, * *$, and $*$ indicate significance at the $1 \%, 5 \%$, and $10 \%$ levels respectively. 


\section{Table 6}

OLS Estimates of the Relation Between Compensation and Firm Performance After Controlling for Risk, for the Sample of 1965 Observations Between 1992 and 1995. ${ }^{1}$

\begin{tabular}{|c|c|c|c|c|c|}
\hline $\begin{array}{c}\text { Compensation } \\
\text { Measure }\end{array}$ & $\alpha_{0}$ & $\alpha_{1}$ & $\alpha_{2}$ & $\begin{array}{l}\text { F-Statistic } \\
\text { (p-value) }\end{array}$ & Adjusted $\mathrm{R}^{2}$ \\
\hline \multicolumn{6}{|c|}{ Panel A: $\operatorname{COMP}_{\mathrm{i}}=\alpha_{0}+\alpha_{1} \mathrm{ROC}_{\mathrm{i}}+\alpha_{2} \mathrm{COC}_{\mathrm{i}}+\varepsilon_{\mathrm{i}}$} \\
\hline SALARY & $\begin{array}{l}-0.413 * * * \\
(-4.17)\end{array}$ & $\begin{array}{l}0.466 \\
(.98)\end{array}$ & $\begin{array}{l}0.066^{* * * *} \\
(5.33)\end{array}$ & $\begin{array}{c}47.653 \\
(<0.01)\end{array}$ & 0.05 \\
\hline BONUS & $\begin{array}{l}-0.371 * * * \\
(-5.12)\end{array}$ & $\begin{array}{l}1.360 \text { *** } \\
(3.85)\end{array}$ & $\begin{array}{l}0.041 \text { *** } \\
(4.91)\end{array}$ & $\begin{array}{l}100.19 \\
(<0.01)\end{array}$ & 0.09 \\
\hline CASHCOMP & $\begin{array}{l}-0.784 * * * \\
(-5.02)\end{array}$ & $\begin{array}{l}1.826^{* * *} \\
(2.38)\end{array}$ & $\begin{array}{l}0.107 * * * \\
(5.56)\end{array}$ & $\begin{array}{c}77.63 \\
(<0.01)\end{array}$ & 0.07 \\
\hline TDC & $\begin{array}{l}-5.439 * * * \\
(-5.63)\end{array}$ & $\begin{array}{l}14.229 \text { *** } \\
(3.17)\end{array}$ & $\begin{array}{l}0.497 * * * \\
(5.57)\end{array}$ & $\begin{array}{c}88.97 \\
(<0.01) \\
\end{array}$ & 0.08 \\
\hline \multicolumn{6}{|c|}{ Panel B: $\mathrm{COMP}_{i}=\alpha_{0}+\alpha_{1} \Delta \mathrm{MVA}_{i}+\alpha_{2} \mathrm{COC}_{\mathrm{i}}+\varepsilon_{\mathrm{I}}$} \\
\hline SALARY & $\begin{array}{l}-0.397 * * * \\
(-4.63)\end{array}$ & $\begin{array}{l}0.001 * * * \\
(3.71)\end{array}$ & $\begin{array}{l}0.067 * * * \\
(8.65)\end{array}$ & $\begin{array}{c}97.15 \\
(<0.01)\end{array}$ & 0.09 \\
\hline BONUS & $\begin{array}{l}-0.467 * * * \\
(-6.83)\end{array}$ & $\begin{array}{l}0.001 \text { *** } \\
(3.03)\end{array}$ & $\begin{array}{l}0.060 \text { *** } \\
(9.24)\end{array}$ & $\begin{array}{l}112.86 \\
(<0.01)\end{array}$ & 0.11 \\
\hline CASHCOMP & $\begin{array}{l}-0.865 * * * \\
(-6.28)\end{array}$ & $\begin{array}{l}0.002^{* * * *} \\
(3.96)\end{array}$ & $\begin{array}{l}0.126^{* * * *} \\
(9.87)\end{array}$ & $\begin{array}{l}125.60 \\
(<0.01)\end{array}$ & 0.11 \\
\hline TDC & $\begin{array}{l}-6.201 * * * \\
(-5.94) \\
\end{array}$ & $\begin{array}{l}0.012^{* * * *} \\
(3.48) \\
\end{array}$ & $\begin{array}{l}0.665^{* * * *} \\
(6.87) \\
\end{array}$ & $\begin{array}{l}150.93 \\
(<0.01) \\
\end{array}$ & 0.13 \\
\hline \multicolumn{6}{|c|}{ Panel C: $\mathrm{COMP}_{\mathrm{i}}=\alpha_{0}+\alpha_{1} \mathrm{SEVA}_{\mathrm{i}}+\alpha_{2} \mathrm{COC}_{\mathrm{i}}+\varepsilon_{\mathrm{I}}$} \\
\hline SALARY & $\begin{array}{l}-0.491 * * * \\
(-3.33)\end{array}$ & $\begin{array}{l}-0.003 \\
(-.257)\end{array}$ & $\begin{array}{l}0.077 * * * \\
(5.76)\end{array}$ & $\begin{array}{c}46.52 \\
(<0.01)\end{array}$ & 0.04 \\
\hline BONUS & $\begin{array}{l}-0.407 * * * \\
(-4.71)\end{array}$ & $\begin{array}{l}0.010 * \\
(1.77)\end{array}$ & $\begin{array}{l}0.057 * * * \\
(7.23)\end{array}$ & $\begin{array}{c}87.60 \\
(<0.01)\end{array}$ & 0.08 \\
\hline CASHCOMP & $\begin{array}{l}-0.898 * * * \\
(-4.06)\end{array}$ & $\begin{array}{l}0.007 \\
(.433)\end{array}$ & $\begin{array}{l}0.134 * * * \\
(6.67)\end{array}$ & $\begin{array}{c}66.79 \\
(<0.01)\end{array}$ & 0.06 \\
\hline TDC & $\begin{array}{l}-5.511 * * * \\
(-5.46)\end{array}$ & $\begin{array}{l}0.127 * * \\
(2.14)\end{array}$ & $\begin{array}{l}0.644^{* * * *} \\
(6.64)\end{array}$ & $\begin{array}{c}90.14 \\
(<0.01) \\
\end{array}$ & 0.08 \\
\hline
\end{tabular}




\section{Table 6 (continued)}

OLS Estimates of the Relation Between Compensation and Firm Performance After Controlling for Risk, for the Sample of 1965 Observations Between 1992 and 1995. ${ }^{1}$

\begin{tabular}{|c|c|c|c|c|c|}
\hline $\begin{array}{c}\text { Compensation } \\
\text { Measure }\end{array}$ & $\alpha_{0}$ & $\alpha_{1}$ & $\alpha_{2}$ & $\begin{array}{c}\text { F-Statistic } \\
\text { (p-value) }\end{array}$ & Adjusted $\mathrm{R}^{2}$ \\
\hline \multicolumn{6}{|c|}{ Panel D: $\mathrm{COMP}_{\mathrm{i}}=\alpha_{0}+\alpha_{1} \mathrm{ROE}_{\mathrm{i}}+\alpha_{2} \mathrm{COC}_{\mathrm{i}}+\varepsilon_{\mathrm{i}}$} \\
\hline SALARY & $\begin{array}{l}-4.61 * * * \\
(-5.27)\end{array}$ & $\begin{array}{c}0.001 \\
(.24)\end{array}$ & $\begin{array}{l}0.075^{* * * *} \\
(9.02)\end{array}$ & $\begin{array}{c}45.57 \\
(<0.01)\end{array}$ & 0.04 \\
\hline BONUS & $\begin{array}{l}-0.511^{* * *} \\
(-7.18)\end{array}$ & $\begin{array}{c}0.013 \\
(1.35)\end{array}$ & $\begin{array}{l}0.065^{* * * *} \\
(9.52)\end{array}$ & $\begin{array}{c}65.75 \\
(<0.01)\end{array}$ & 0.06 \\
\hline CASHCOMP & $\begin{array}{l}-0.972 * * * \\
(-6.81)\end{array}$ & $\begin{array}{c}0.014 \\
(1.20)\end{array}$ & $\begin{array}{l}0.140 * * * \\
(10.27)\end{array}$ & $\begin{array}{c}64.51 \\
(<0.01)\end{array}$ & 0.06 \\
\hline TDC & $\begin{array}{l}-6.90 * * * \\
(-5.71)\end{array}$ & $\begin{array}{c}0.055 \\
(1.12) \\
\end{array}$ & $\begin{array}{l}0.755^{* * * *} \\
(6.58)\end{array}$ & $\begin{array}{c}62.10 \\
(<0.01) \\
\end{array}$ & 0.06 \\
\hline \multicolumn{6}{|c|}{ Panel E: $\mathrm{COMP}_{\mathrm{i}}=\alpha_{0}+\alpha_{1} \mathrm{ROA}_{\mathrm{i}}+\alpha_{2} \mathrm{COC}_{\mathrm{i}}+\varepsilon_{\mathrm{I}}$} \\
\hline SALARY & $\begin{array}{l}-0.399 * * * \\
(-4.28)\end{array}$ & $\begin{array}{l}0.582^{* * * *} \\
(2.72)\end{array}$ & $\begin{array}{l}0.067 * * * \\
(7.34)\end{array}$ & $\begin{array}{c}48.02 \\
(<0.01)\end{array}$ & 0.05 \\
\hline BONUS & $\begin{array}{l}-0.351 * * * \\
(-4.77)\end{array}$ & $\begin{array}{l}1.518^{* * * *} \\
(4.38)\end{array}$ & $\begin{array}{l}0.045^{* * * *} \\
(6.17)\end{array}$ & $\begin{array}{c}97.93 \\
(<0.01)\end{array}$ & 0.09 \\
\hline CASHCOMP & $\begin{array}{l}-0.750 * * * \\
(-4.98)\end{array}$ & $\begin{array}{l}2.099 * * * \\
(4.02)\end{array}$ & $\begin{array}{l}0.112 * * * \\
(7.56)\end{array}$ & $\begin{array}{c}77.56 \\
(<0.01)\end{array}$ & 0.07 \\
\hline $\mathrm{TDC}$ & $\begin{array}{l}-5.553 * * * \\
(-5.39)\end{array}$ & $\begin{array}{l}12.757 * * * \\
(3.80)\end{array}$ & $\begin{array}{l}0.584 * * * \\
(6.21)\end{array}$ & $\begin{array}{c}78.17 \\
(<0.01)\end{array}$ & 0.07 \\
\hline
\end{tabular}

${ }^{1} \mathrm{COMP}_{\mathrm{i}}$ is the measure of executive compensation, $\mathrm{ROC}_{\mathrm{i}}$ is the return on total capital, $\mathrm{COC}_{\mathrm{i}}$ is the cost of capital, $\triangle \mathrm{MVA}_{\mathrm{i}}$ is the change in market value added, $\mathrm{SEVA}_{\mathrm{i}}$ is the standardized economic value added, $\mathrm{ROE}_{\mathrm{i}}$ is the return on equity, and $\mathrm{ROA}_{\mathrm{i}}$ is the return on assets for firm i. t-statistics are in parenthesis. ***,**, and * indicate significance at the $1 \%, 5 \%$, and $10 \%$ levels respectively. 


\section{Table 7}

Tests for the Relative Explanatory Power of Performance Measures for the Sample of 1965 Observations Between 1992 and 1995.

\begin{tabular}{|c|c|c|c|c|c|c|c|c|}
\hline $\begin{array}{c}\text { Compensation } \\
\text { Measure }\end{array}$ & Intercept & $\mathrm{COC}$ & ROA & ROC & SEVA & $\Delta \mathrm{MVA}$ & $\begin{array}{c}\text { F-Statistic } \\
\text { (p-value) }\end{array}$ & Adjusted $\mathrm{R}^{2}$ \\
\hline SALARY & $\begin{array}{l}-0.345^{* * *} \\
(-3.87)\end{array}$ & $\begin{array}{l}0.060 * * * \\
(7.08)\end{array}$ & $\begin{array}{l}0.496 * * \\
(2.41)\end{array}$ & & & $\begin{array}{l}0.109 * * * \\
(3.68)\end{array}$ & $\begin{array}{l}66.04 \\
<0.01\end{array}$ & 0.09 \\
\hline BONUS & $\begin{array}{l}-0.314 * * * \\
(-4.27)\end{array}$ & $\begin{array}{l}0.040 * * * \\
(5.47)\end{array}$ & $\begin{array}{l}1.459 * * * \\
(4.44)\end{array}$ & & & $\begin{array}{l}0.074 * * * \\
(3.07)\end{array}$ & $\begin{array}{l}97.05 \\
<0.01\end{array}$ & 0.13 \\
\hline CASHCOMP & $\begin{array}{l}-0.658 * * * \\
(-4.49)\end{array}$ & $\begin{array}{l}0.100 * * * \\
(7.02)\end{array}$ & $\begin{array}{l}1.955^{* * *} \\
(4.00)\end{array}$ & & & $\begin{array}{l}0.183 \text { *** } \\
(3.95)\end{array}$ & $\begin{array}{l}92.19 \\
<0.01\end{array}$ & 0.12 \\
\hline TDC & $\begin{array}{l}-2.033 * * * \\
(-5.54)\end{array}$ & $\begin{array}{l}0.262 * * * \\
(7.48)\end{array}$ & $\begin{array}{l}3.232 * * * \\
(3.00)\end{array}$ & & & $\begin{array}{l}0.629 * * * \\
(3.33)\end{array}$ & $\begin{array}{l}98.13 \\
<0.01\end{array}$ & 0.13 \\
\hline SALARY & $\begin{array}{l}-0.418^{* * * *} \\
(-4.08)\end{array}$ & $\begin{array}{l}0.064 * * * \\
(6.74)\end{array}$ & $\begin{array}{c}1.388 \\
(0.95)\end{array}$ & & $\begin{array}{r}-0.949 \\
(-0.54)\end{array}$ & & $\begin{array}{l}36.48 \\
<0.01\end{array}$ & 0.05 \\
\hline BONUS & $\begin{array}{l}-0.343 * * * \\
(-4.54)\end{array}$ & $\begin{array}{l}0.046 * * * \\
(6.38)\end{array}$ & $\begin{array}{l}1.206^{* *} \\
(1.85)\end{array}$ & & $\begin{array}{r}0.367 \\
(0.47)\end{array}$ & & $\begin{array}{l}66.60 \\
<0.01\end{array}$ & 0.09 \\
\hline CASHCOMP & $\begin{array}{l}-0.761 * * * \\
(-4.69)\end{array}$ & $\begin{array}{l}0.111 * * * \\
(7.30)\end{array}$ & $\begin{array}{c}2.594 \\
(1.25)\end{array}$ & & $\begin{array}{l}-0.583 \\
(-0.23)\end{array}$ & & $\begin{array}{l}52.38 \\
<0.01\end{array}$ & 0.07 \\
\hline TDC & $\begin{array}{l}-2.334 * * * \\
(-5.65)\end{array}$ & $\begin{array}{l}0.304 * * * \\
(7.56)\end{array}$ & $\begin{array}{c}3.243 \\
(0.76)\end{array}$ & & $\begin{array}{r}0.569 \\
(0.11)\end{array}$ & & $\begin{array}{l}37.91 \\
<0.01\end{array}$ & 0.05 \\
\hline
\end{tabular}

\footnotetext{
${ }^{1} \mathrm{t}$-statistics are in parenthesis. $* * *, * *$, and $*$ indicate significance at the $1 \%, 5 \%$, and $10 \%$ levels respectively.
} 


\section{Table 7 (continued)}

Tests for the Relative Explanatory Power of Performance Measures for the Sample of 1965 Observations Between 1992 and 1995.

\begin{tabular}{|c|c|c|c|c|c|c|c|c|}
\hline $\begin{array}{c}\text { Compensation } \\
\text { Measure } \\
\end{array}$ & Intercept & $\mathrm{COC}$ & ROA & ROC & SEVA & $\Delta \mathrm{MVA}$ & $\begin{array}{c}\text { F-Statistic } \\
\text { (p-value) }\end{array}$ & Adjusted $\mathrm{R}^{2}$ \\
\hline SALARY & $\begin{array}{l}-0.395 * * * \\
(-4.20)\end{array}$ & $\begin{array}{l}0.065^{* * * *} \\
(5.63)\end{array}$ & $\begin{array}{c}0.404 \\
(0.62)\end{array}$ & $\begin{array}{r}0.220 \\
(0.26)\end{array}$ & & & $\begin{array}{l}32.15 \\
<0.01\end{array}$ & 0.05 \\
\hline BONUS & $\begin{array}{l}-0.336^{* * *} \\
(-4.57)\end{array}$ & $\begin{array}{l}0.039 * * * \\
(4.71)\end{array}$ & $\begin{array}{l}0.822^{* *} \\
(2.19)\end{array}$ & $\begin{array}{l}0.859 * * \\
(2.02)\end{array}$ & & & $\begin{array}{l}70.10 \\
<0.01\end{array}$ & 0.10 \\
\hline CASHCOMP & $\begin{array}{l}-0.731 * * * \\
(-4.83)\end{array}$ & $\begin{array}{l}0.104^{* * * *} \\
(5.70)\end{array}$ & $\begin{array}{l}1.225 \\
(1.27)\end{array}$ & $\begin{array}{r}1.079 \\
(0.89)\end{array}$ & & & $\begin{array}{l}53.26 \\
<0.01\end{array}$ & 0.07 \\
\hline TDC & $\begin{array}{l}-2.289 * * * \\
(-5.73)\end{array}$ & $\begin{array}{l}0.279 * * * \\
(6.30)\end{array}$ & $\begin{array}{r}1.021 \\
(0.46)\end{array}$ & $\begin{array}{c}3.338 \\
(1.20)\end{array}$ & & & $\begin{array}{l}39.69 \\
<0.01\end{array}$ & 0.06 \\
\hline SALARY & $\begin{array}{l}-0.372 * * * \\
(-3.94)\end{array}$ & $\begin{array}{l}0.052 * * * \\
(4.66)\end{array}$ & $\begin{array}{r}2.297 \\
(1.34)\end{array}$ & & $\begin{array}{c}-2.152 \\
(-1.03)\end{array}$ & $\begin{array}{l}0.142 * * * \\
(2.59)\end{array}$ & $\begin{array}{l}66.50 \\
<0.01\end{array}$ & 0.12 \\
\hline BONUS & $\begin{array}{l}-0.317 * * * \\
(-4.26)\end{array}$ & $\begin{array}{l}0.039 * * * \\
(4.96)\end{array}$ & $\begin{array}{l}1.713^{* *} \\
(2.22)\end{array}$ & & $\begin{array}{c}-0.303 \\
(-0.34)\end{array}$ & $\begin{array}{l}0.079 * * \\
(2.57)\end{array}$ & $\begin{array}{l}73.40 \\
<0.01\end{array}$ & 0.13 \\
\hline CASHCOMP & $\begin{array}{l}-0.689 * * * \\
(-4.49)\end{array}$ & $\begin{array}{l}0.091^{* * * *} \\
(5.19)\end{array}$ & $\begin{array}{c}4.010 \\
(1.64)\end{array}$ & & $\begin{array}{c}-2.456 \\
(-0.83)\end{array}$ & $\begin{array}{l}0.221^{* * * *} \\
(2.79)\end{array}$ & $\begin{array}{l}78.32 \\
<0.01\end{array}$ & 0.14 \\
\hline TDC & $\begin{array}{l}-2.101 * * * \\
(-5.53)\end{array}$ & $\begin{array}{l}0.243^{* * * *} \\
(5.87)\end{array}$ & $\begin{array}{r}7.809 \\
(1.55)\end{array}$ & & $\begin{array}{c}-5.471 \\
(-0.90)\end{array}$ & $\begin{array}{l}0.713^{* * * *} \\
(2.97)\end{array}$ & $\begin{array}{l}79.48 \\
<0.01\end{array}$ & 0.14 \\
\hline
\end{tabular}

\footnotetext{
${ }^{1} \mathrm{t}$-statistics are in parenthesis. $* * *, * *$, and $*$ indicate significance at the $1 \%, 5 \%$, and $10 \%$ levels respectively.
} 


\section{Table 8}

Descriptive Statistics (Means) for Sub-Samples of Firms Based on SEVA and $\triangle$ MVA Values ${ }^{1}$

\begin{tabular}{lcc}
\hline & High SEVA / High $\Delta$ MVA & High SEVA / Low $\Delta$ MVA \\
\hline $\mathrm{N}$ & 233 & 234 \\
SEVA & 0.0968 & 0.0707 \\
$\Delta \mathrm{MVA}$ & 2.4140 & -0.9965 \\
Salary & & \\
Bonus & 0.7402 & 0.4232 \\
CashComp & 0.5832 & 0.3121 \\
TDC & 1.3234 & 0.7353 \\
\hline & 3.2179 & 1.4199 \\
\hline $\mathrm{N}$ & Low SEVA / High $\Delta \mathrm{MVA}$ & Low SEVA / Low $\Delta \mathrm{MVA}$ \\
& 225 & 198 \\
SEVA & & -0.0752 \\
$\Delta \mathrm{MVA}$ & -0.0801 & -0.8697 \\
Salary & 1.2463 & 0.3232 \\
Bonus & & 0.1295 \\
CashComp & 0.4549 & 0.4527 \\
TDC & 0.2406 & 0.9646 \\
\hline
\end{tabular}

${ }^{1}$ Compensation variables are expressed as percent of BOYCAP. 
Table 9

SEVA and $\triangle$ MVA Regressions for HH/HL/LH/LL groups (3x3 sorting, only 4 used in estimation)

\begin{tabular}{|c|c|c|c|c|c|c|c|c|}
\hline & Salary & Bonus & CashComp & TDC & Salary & Bonus & CashComp & TDC \\
\hline & \multicolumn{4}{|c|}{ High SEVA / High $\Delta \mathrm{MVA}$} & \multicolumn{4}{|c|}{ High SEVA / Low $\Delta \mathrm{MVA}$} \\
\hline $\mathrm{N}$ & 233 & 233 & 233 & 233 & 234 & 234 & 234 & 234 \\
\hline Intercept & $\begin{array}{c}-0.539 \\
(-1.40)\end{array}$ & $\begin{array}{c}-0.630 \\
(-1.50)\end{array}$ & $\begin{array}{l}-1.169 * * \\
(-1.68)\end{array}$ & $\begin{array}{l}-3.972 \\
(-1.44)\end{array}$ & $\begin{array}{r}0.020 \\
(0.11)\end{array}$ & $\begin{array}{c}-0.207 \\
(-1.09)\end{array}$ & $\begin{array}{l}-0.187 \\
(-0.67)\end{array}$ & $\begin{array}{l}-1.823^{* *} \\
(-1.70)\end{array}$ \\
\hline $\mathrm{COC}$ & $\begin{array}{l}0.094^{* * * *} \\
(3.15)\end{array}$ & $\begin{array}{l}0.084 * * \\
(2.59)\end{array}$ & $\begin{array}{l}0.179 * * * \\
(3.05)\end{array}$ & $\begin{array}{l}0.509 * * \\
(2.38)\end{array}$ & $\begin{array}{l}0.025 * * \\
(1.76)\end{array}$ & $\begin{array}{l}0.029 * * \\
(1.95)\end{array}$ & $\begin{array}{l}0.055^{* * *} \\
(2.38)\end{array}$ & $\begin{array}{l}0.227 * * \\
(2.57)\end{array}$ \\
\hline SEVA & $\begin{array}{c}0.606 \\
(1.21)\end{array}$ & $\begin{array}{l}1.240 * * \\
(2.28)\end{array}$ & $\begin{array}{l}1.846 \\
(1.60)\end{array}$ & $\begin{array}{l}6.144 * * \\
(1.72)\end{array}$ & $\begin{array}{l}1.191^{* * * *} \\
(3.29)\end{array}$ & $\begin{array}{l}2.099 * * * \\
(5.52)\end{array}$ & $\begin{array}{l}3.290 * * * \\
(3.63)\end{array}$ & $\begin{array}{l}5.328 * * \\
(2.21)\end{array}$ \\
\hline F-Stat & $\begin{array}{r}6.92 \\
<0.01\end{array}$ & $\begin{array}{r}7.64 \\
<0.01\end{array}$ & $\begin{array}{r}9.37 \\
<0.01\end{array}$ & $\begin{array}{r}5.50 \\
<0.01\end{array}$ & $\begin{array}{r}8.32 \\
<0.01\end{array}$ & $\begin{array}{l}19.83 \\
<0.01\end{array}$ & $\begin{array}{l}19.08 \\
<0.01\end{array}$ & $\begin{array}{l}11.08 \\
<0.01\end{array}$ \\
\hline Adj. Rsq. & 0.05 & 0.05 & 0.07 & 0.04 & 0.06 & 0.14 & 0.13 & 0.08 \\
\hline \multicolumn{5}{|c|}{ Low SEVA / High $\Delta$ MVA } & \multicolumn{4}{|c|}{ Low SEVA / Low $\triangle \mathrm{MVA}$} \\
\hline $\mathrm{N}$ & 225 & 225 & 225 & 225 & 198 & 198 & 198 & 198 \\
\hline Intercept & $\begin{array}{l}-2.035^{* *} \\
(-2.26)\end{array}$ & $\begin{array}{l}-1.077 * * \\
(-2.49)\end{array}$ & $\begin{array}{l}-3.113^{* *} \\
(-2.38)\end{array}$ & $\begin{array}{l}-6.436 * * \\
(-2.45)\end{array}$ & $\begin{array}{l}-0.330 * * * \\
(-2.83)\end{array}$ & $\begin{array}{l}-0.276^{* *} \\
(-2.11)\end{array}$ & $\begin{array}{l}-0.606^{* *} \\
(-2.37)\end{array}$ & $\begin{array}{l}-2.186^{* *} \\
(-2.44)\end{array}$ \\
\hline $\mathrm{COC}$ & $\begin{array}{l}0.062 * * \\
(2.54)\end{array}$ & $\begin{array}{l}0.061 * * * \\
(2.62)\end{array}$ & $\begin{array}{l}0.123^{* * * *} \\
(2.85)\end{array}$ & $\begin{array}{l}0.276^{* * * *} \\
(2.74)\end{array}$ & $\begin{array}{l}0.052 * * * \\
(4.48)\end{array}$ & $\begin{array}{l}0.039 * * * \\
(3.89)\end{array}$ & $\begin{array}{l}0.092 * * * \\
(3.22)\end{array}$ & $\begin{array}{l}0.279 * * * \\
(4.02)\end{array}$ \\
\hline SEVA & $\begin{array}{l}-22.507 * * \\
(-1.98)\end{array}$ & $\begin{array}{r}-8.031 \\
(-1.62)\end{array}$ & $\begin{array}{l}-30.538^{* *} \\
(-1.88)\end{array}$ & $\begin{array}{l}-60.388 * * \\
(-1.87)\end{array}$ & $\begin{array}{c}-0.480 \\
(-0.79)\end{array}$ & $\begin{array}{c}0.796 \\
(1.17)\end{array}$ & $\begin{array}{c}0.316 \\
(0.32)\end{array}$ & $\begin{array}{l}1.843 \\
(0.40)\end{array}$ \\
\hline F-Stat & $\begin{array}{r}101.72 \\
<0.01\end{array}$ & $\begin{array}{l}49.46 \\
<0.01\end{array}$ & $\begin{array}{l}87.96 \\
<0.01\end{array}$ & $\begin{array}{l}74.07 \\
<0.01\end{array}$ & $\begin{array}{l}17.84 \\
<0.01\end{array}$ & $\begin{array}{r}8.08 \\
<0.01\end{array}$ & $\begin{array}{l}15.03 \\
<0.01\end{array}$ & $\begin{array}{r}8.12 \\
<0.01\end{array}$ \\
\hline Adj. Rsq. & 0.47 & 0.30 & 0.44 & 0.39 & 0.15 & 0.07 & 0.12 & 0.07 \\
\hline
\end{tabular}




\section{Table 9 (continued)}

SEVA and $\triangle$ MVA Regressions for HH/HL/LH/LL groups ( $3 \times 3$ sorting, only 4 used in estimation)

\begin{tabular}{|c|c|c|c|c|c|c|c|c|}
\hline & Salary & Bonus & CashComp & TDC & Salary & Bonus & CashComp & TDC \\
\hline & \multicolumn{4}{|c|}{ High SEVA / High $\Delta \mathrm{MVA}$} & \multicolumn{4}{|c|}{ High SEVA / Low $\Delta \mathrm{MVA}$} \\
\hline $\mathrm{N}$ & 233 & 233 & 233 & 233 & 234 & 234 & 234 & 234 \\
\hline Intercept & $\begin{array}{l}-0.317 \\
(-0.86)\end{array}$ & $\begin{array}{l}-0.542 \\
(-1.29)\end{array}$ & $\begin{array}{c}-0.859 \\
(-1.20)\end{array}$ & $\begin{array}{l}-2.289 \\
(-0.87)\end{array}$ & $\begin{array}{l}-0.007 \\
(-0.04)\end{array}$ & $\begin{array}{c}-0.254 \\
(-1.27)\end{array}$ & $\begin{array}{c}-0.261 \\
(-0.79)\end{array}$ & $\begin{array}{l}-1.943^{* *} \\
(-1.72)\end{array}$ \\
\hline $\mathrm{COC}$ & $\begin{array}{l}0.063 * * \\
(2.16)\end{array}$ & $\begin{array}{l}0.074 * * \\
(2.25)\end{array}$ & $\begin{array}{l}0.137 * * \\
(2.22)\end{array}$ & $\begin{array}{c}0.272 \\
(1.32)\end{array}$ & $\begin{array}{l}0.032 * * \\
(2.13)\end{array}$ & $\begin{array}{l}0.038 * * \\
(2.34)\end{array}$ & $\begin{array}{l}0.069 * * * \\
(2.62)\end{array}$ & $\begin{array}{l}0.252 * * * \\
(2.70)\end{array}$ \\
\hline$\Delta \mathrm{MVA}$ & $\begin{array}{l}0.103^{* * * *} \\
(4.86)\end{array}$ & $\begin{array}{l}0.070 * * * \\
(2.91)\end{array}$ & $\begin{array}{l}0.173 * * \\
(2.50)\end{array}$ & $\begin{array}{l}0.825^{* * * *} \\
(5.50)\end{array}$ & $\begin{array}{l}-0.032 \\
(-0.75)\end{array}$ & $\begin{array}{l}-0.092 * * \\
(-1.99)\end{array}$ & $\begin{array}{l}-0.124 \\
(-1.63)\end{array}$ & $\begin{array}{c}-0.184 \\
(-0.53)\end{array}$ \\
\hline F-Stat & $\begin{array}{l}18.61 \\
<0.01\end{array}$ & $\begin{array}{r}9.34 \\
<0.01\end{array}$ & $\begin{array}{l}17.52 \\
<0.01\end{array}$ & $\begin{array}{l}19.60 \\
<0.01\end{array}$ & $\begin{array}{l}3.07 \\
0.05\end{array}$ & $\begin{array}{r}6.09 \\
<0.01\end{array}$ & $\begin{array}{r}6.07 \\
<0.01\end{array}$ & $\begin{array}{r}7.03 \\
<0.01\end{array}$ \\
\hline Adj. Rsq. & 0.13 & 0.07 & 0.12 & 0.14 & 0.02 & 0.04 & 0.04 & 0.05 \\
\hline \multicolumn{5}{|c|}{ Low SEVA / High $\triangle \mathrm{MVA}$} & \multicolumn{4}{|c|}{ Low SEVA / Low $\triangle \mathrm{MVA}$} \\
\hline $\mathrm{N}$ & 225 & 225 & 225 & 225 & 198 & 198 & 198 & 198 \\
\hline Intercept & $\begin{array}{l}-1.494 * * * \\
(-2.84)\end{array}$ & $\begin{array}{l}-0.904 * * * \\
(-3.56)\end{array}$ & $\begin{array}{l}-2.397 * * \\
(-1.95)\end{array}$ & $\begin{array}{l}-5.039 * * * \\
(-3.17)\end{array}$ & $\begin{array}{l}-0.236^{* *} \\
(-2.15)\end{array}$ & $\begin{array}{l}-0.218 * * \\
(-1.70)\end{array}$ & $\begin{array}{l}-0.454 * * \\
(-2.14)\end{array}$ & $\begin{array}{l}-1.783^{* *} \\
(-2.02)\end{array}$ \\
\hline $\mathrm{COC}$ & $\begin{array}{r}0.007 \\
(0.15)\end{array}$ & $\begin{array}{l}0.040 * * \\
(1.79)\end{array}$ & $\begin{array}{c}0.046 \\
(0.75)\end{array}$ & $\begin{array}{l}0.123 \\
(0.89)\end{array}$ & $\begin{array}{l}0.054 * * * \\
(4.57)\end{array}$ & $\begin{array}{l}0.041 * * * \\
(4.10)\end{array}$ & $\begin{array}{l}0.095^{* * * *} \\
(5.74)\end{array}$ & $\begin{array}{l}0.288 * * * \\
(4.17)\end{array}$ \\
\hline$\Delta \mathrm{MVA}$ & $\begin{array}{l}1.503^{* * * *} \\
(7.74)\end{array}$ & $\begin{array}{l}0.565^{* * * *} \\
(6.03)\end{array}$ & $\begin{array}{r}2.069 \\
(1.39)\end{array}$ & $\begin{array}{l}4.115^{* * * *} \\
(7.02)\end{array}$ & $\begin{array}{r}0.087 \\
(1.38)\end{array}$ & $\begin{array}{l}0.157 * * \\
(2.57)\end{array}$ & $\begin{array}{l}0.245^{* *} \\
(2.42)\end{array}$ & $\begin{array}{l}0.745 * * \\
(1.77)\end{array}$ \\
\hline F-Stat & $\begin{array}{l}31.76 \\
<0.01\end{array}$ & $\begin{array}{l}23.26 \\
<0.01\end{array}$ & $\begin{array}{l}30.56 \\
<0.01\end{array}$ & $\begin{array}{l}27.69 \\
<0.01\end{array}$ & $\begin{array}{l}18.99 \\
<0.01\end{array}$ & $\begin{array}{l}10.89 \\
<0.01\end{array}$ & $\begin{array}{l}18.36 \\
<0.01\end{array}$ & $\begin{array}{r}9.72 \\
<0.01\end{array}$ \\
\hline Adj. Rsq. & 0.22 & 0.17 & 0.21 & 0.19 & 0.15 & 0.09 & 0.15 & 0.08 \\
\hline
\end{tabular}


Table 10

SEVA and $\triangle$ MVA Regressions for HH/HL/LH/LL groups ( $3 \times 3$ sorting, only 4 used in estimation)

\begin{tabular}{|c|c|c|c|c|c|c|c|c|}
\hline & Salary & Bonus & CashComp & TDC & Salary & Bonus & CashComp & TDC \\
\hline & \multicolumn{4}{|c|}{ High SEVA / High $\Delta \mathrm{MVA}$} & \multicolumn{4}{|c|}{ High SEVA / Low $\Delta \mathrm{MVA}$} \\
\hline $\mathrm{N}$ & 233 & 233 & 233 & 233 & 234 & 234 & 234 & 234 \\
\hline Intercept & $\begin{array}{c}-0.323 \\
(-0.68)\end{array}$ & $\begin{array}{c}-0.540 \\
(-1.29)\end{array}$ & $\begin{array}{c}-0.863 \\
(-1.21)\end{array}$ & $\begin{array}{c}-2.326 \\
(-1.41)\end{array}$ & $\begin{array}{c}0.020 \\
(0.11)\end{array}$ & $\begin{array}{c}-0.208 \\
(-1.10)\end{array}$ & $\begin{array}{c}-0.188 \\
(-0.60)\end{array}$ & $\begin{array}{l}-1.825^{* *} \\
(-1.69)\end{array}$ \\
\hline $\mathrm{COC}$ & $\begin{array}{l}0.066^{* *} \\
(1.67)\end{array}$ & $\begin{array}{l}0.073^{* *} \\
(2.20)\end{array}$ & $\begin{array}{l}0.139 * * \\
(2.26)\end{array}$ & $\begin{array}{l}0.296^{* *} \\
(2.12)\end{array}$ & $\begin{array}{c}0.024 \\
(1.64)\end{array}$ & $\begin{array}{r}0.025 \\
(1.61)\end{array}$ & $\begin{array}{l}0.049 * * \\
(1.93)\end{array}$ & $\begin{array}{l}0.220 * * \\
(2.44)\end{array}$ \\
\hline SEVA & $\begin{array}{c}-1.330 \\
(-1.49)\end{array}$ & $\begin{array}{c}0.436 \\
(0.63)\end{array}$ & $\begin{array}{c}-0.894 \\
(-0.72)\end{array}$ & $\begin{array}{c}-8.586 \\
(-0.92)\end{array}$ & $\begin{array}{l}1.174^{* * * *} \\
(3.21)\end{array}$ & $\begin{array}{l}2.032 * * * \\
(5.32)\end{array}$ & $\begin{array}{l}3.207 * * * \\
(5.09)\end{array}$ & $\begin{array}{l}5.211^{* *} \\
(2.36)\end{array}$ \\
\hline$\Delta \mathrm{MVA}$ & $\begin{array}{l}0.139 * * * \\
(2.68)\end{array}$ & $\begin{array}{l}0.058^{* * *} \\
(1.89)\end{array}$ & $\begin{array}{l}0.197 * * * \\
(2.69)\end{array}$ & $\begin{array}{l}1.060 * * \\
(1.93)\end{array}$ & $\begin{array}{r}-0.015 \\
(-0.36)\end{array}$ & $\begin{array}{c}-0.063 \\
(-1.43)\end{array}$ & $\begin{array}{c}-0.078 \\
(-1.08)\end{array}$ & $\begin{array}{c}-0.110 \\
(-0.36)\end{array}$ \\
\hline F-Stat & $\begin{array}{l}14.25 \\
<0.01\end{array}$ & $\begin{array}{r}6.35 \\
<0.01\end{array}$ & $\begin{array}{l}11.88 \\
<0.01\end{array}$ & $\begin{array}{l}14.59 \\
<0.01\end{array}$ & $\begin{array}{r}5.57 \\
<0.01\end{array}$ & $\begin{array}{l}13.96 \\
<0.01\end{array}$ & $\begin{array}{l}13.12 \\
<0.01\end{array}$ & $\begin{array}{r}7.45 \\
<0.01\end{array}$ \\
\hline Adj. Rsq. & 0.15 & 0.06 & 0.12 & 0.15 & 0.06 & 0.14 & 0.13 & 0.08 \\
\hline
\end{tabular}


Table 10 (continued)

SEVA and $\triangle$ MVA Regressions for HH/HL/LH/LL groups (3x3 sorting, only 4 used in estimation)

\begin{tabular}{|c|c|c|c|c|c|c|c|c|}
\hline & Salary & Bonus & CashComp & TDC & Salary & Bonus & CashComp & $\mathrm{TDC}$ \\
\hline & \multicolumn{4}{|c|}{ Low SEVA / High $\Delta \mathrm{MVA}$} & \multicolumn{4}{|c|}{ Low SEVA / Low $\triangle \mathrm{MVA}$} \\
\hline $\mathrm{N}$ & 225 & 225 & 225 & 225 & 198 & 198 & 198 & 198 \\
\hline Intercept & $\begin{array}{l}-2.486 * * * \\
(-2.67)\end{array}$ & $\begin{array}{l}-1.253 * * * \\
(-2.82)\end{array}$ & $\begin{array}{l}-3.739 * * * \\
(-2.75)\end{array}$ & $\begin{array}{l}-7.689 * * * \\
(-2.80)\end{array}$ & $\begin{array}{l}-0.265^{* *} \\
(-2.52)\end{array}$ & $\begin{array}{c}-0.151 \\
(-1.10)\end{array}$ & $\begin{array}{l}-0.416^{* * *} \\
(-1.83)\end{array}$ & $\begin{array}{l}-1.603^{* *} \\
(-1.69)\end{array}$ \\
\hline $\mathrm{COC}$ & $\begin{array}{c}0.016 \\
(0.50)\end{array}$ & $\begin{array}{r}0.043 \\
(1.62)\end{array}$ & $\begin{array}{c}0.058 \\
(1.11)\end{array}$ & $\begin{array}{c}0.147 \\
(1.24)\end{array}$ & $\begin{array}{l}0.053^{* * * *} \\
(4.48)\end{array}$ & $\begin{array}{l}0.042^{* * * *} \\
(4.17)\end{array}$ & $\begin{array}{l}0.095^{* * * *} \\
(5.74)\end{array}$ & $\begin{array}{l}0.289 * * * \\
(4.19)\end{array}$ \\
\hline SEVA & $\begin{array}{l}-19.821 * * \\
(-2.16)\end{array}$ & $\begin{array}{l}-6.983^{* *} \\
(-1.72)\end{array}$ & $\begin{array}{l}-26.804 * * \\
(-2.03)\end{array}$ & $\begin{array}{l}-52.929 * * \\
(-2.02)\end{array}$ & $\begin{array}{c}-0.410 \\
(-0.68)\end{array}$ & $\begin{array}{r}0.931 \\
(1.38)\end{array}$ & $\begin{array}{r}0.520 \\
(0.47)\end{array}$ & $\begin{array}{c}2.472 \\
(0.53)\end{array}$ \\
\hline$\Delta \mathrm{MVA}$ & $\begin{array}{l}0.947 * * \\
(2.55)\end{array}$ & $\begin{array}{l}0.370^{* *} \\
(1.92)\end{array}$ & $\begin{array}{l}1.317 * * \\
(2.37)\end{array}$ & $\begin{array}{l}2.630 * * \\
(2.16)\end{array}$ & $\begin{array}{c}0.084 \\
(1.30)\end{array}$ & $\begin{array}{l}0.164 * * * \\
(2.67)\end{array}$ & $\begin{array}{l}0.248^{* *} \\
(2.44)\end{array}$ & $\begin{array}{l}0.762^{* * *} \\
(1.80)\end{array}$ \\
\hline F-Stat & $\begin{array}{l}91.84 \\
<0.01\end{array}$ & $\begin{array}{l}41.71 \\
<0.01\end{array}$ & $\begin{array}{l}78.25 \\
<0.01\end{array}$ & $\begin{array}{l}64.54 \\
<0.01\end{array}$ & $\begin{array}{l}12.78 \\
<0.01\end{array}$ & $\begin{array}{r}7.93 \\
<0.01\end{array}$ & $\begin{array}{l}12.27 \\
<0.01\end{array}$ & $\begin{array}{r}6.55 \\
<0.01\end{array}$ \\
\hline Adj. Rsq. & 0.55 & 0.35 & 0.51 & 0.46 & 0.15 & 0.10 & 0.15 & 0.08 \\
\hline
\end{tabular}




\section{Table 11}

Test of the Reward/Incentive Hypothesis for EVA as a Determinant of Compensation, For the Sample 1871 Observations in 1992 and 1993.

\begin{tabular}{|c|c|c|c|c|}
\hline & Salary & Bonus & CashComp & TDC \\
\hline Intercept & $\begin{array}{l}-1.776^{* * * *} \\
(-4.38)\end{array}$ & $\begin{array}{l}-1.497 * * * \\
(-4.65)\end{array}$ & $\begin{array}{l}-3.273^{* * * *} \\
(-5.00)\end{array}$ & $\begin{array}{l}-6.073 * * * \\
(-3.98)\end{array}$ \\
\hline $\mathrm{COC}_{t}$ & $\begin{array}{l}0.373 * * * \\
(9.65)\end{array}$ & $\begin{array}{l}0.258 * * * \\
(8.51)\end{array}$ & $\begin{array}{l}0.631 * * * \\
(10.12)\end{array}$ & $\begin{array}{l}1.167 * * * \\
(7.80)\end{array}$ \\
\hline $\mathrm{SEVA}_{\mathrm{t}-2}$ & $\begin{array}{r}3.937 \\
(1.52)\end{array}$ & $\begin{array}{l}1.485 \\
(0.90)\end{array}$ & $\begin{array}{l}5.421 \\
(1.45)\end{array}$ & $\begin{array}{r}1.609 \\
(0.24)\end{array}$ \\
\hline $\mathrm{SEVA}_{\mathrm{t}-1}$ & $\begin{array}{r}0.760 \\
(0.00)\end{array}$ & $\begin{array}{l}-2.205 \\
(0.00)\end{array}$ & $\begin{array}{l}-1.444 \\
(0.00)\end{array}$ & $\begin{array}{c}10.039 \\
(0.00)\end{array}$ \\
\hline $\mathrm{SEVA}_{0}$ & $\begin{array}{l}-7.345 \\
(-0.71)\end{array}$ & $\begin{array}{r}1.352 \\
(0.42)\end{array}$ & $\begin{array}{l}-5.994 \\
(-0.45)\end{array}$ & $\begin{array}{c}-16.390 \\
(-0.69)\end{array}$ \\
\hline $\mathrm{SEVA}_{\mathrm{t}+1}$ & $\begin{array}{l}12.255^{* * *} \\
(1.80)\end{array}$ & $\begin{array}{l}7.893 * * * \\
(2.92)\end{array}$ & $\begin{array}{l}20.148 * * \\
(2.21)\end{array}$ & $\begin{array}{c}7.002 \\
(0.40)\end{array}$ \\
\hline $\mathrm{SEVA}_{\mathrm{t}+2}$ & $\begin{array}{l}-4.485^{* *} \\
(-2.07)\end{array}$ & $\begin{array}{c}-0.139 \\
(-0.11)\end{array}$ & $\begin{array}{c}-4.624 \\
(-1.51)\end{array}$ & $\begin{array}{l}15.677 * * \\
(2.17)\end{array}$ \\
\hline $\begin{array}{l}\text { F-Statistic } \\
\text { (p-value) }\end{array}$ & $\begin{array}{l}38.45 \\
<0.01\end{array}$ & $\begin{array}{l}48.72 \\
<0.01\end{array}$ & $\begin{array}{l}47.95 \\
<0.01\end{array}$ & $\begin{array}{r}9.72 \\
<0.01\end{array}$ \\
\hline R-Square & 0.11 & 0.13 & 0.13 & 0.03 \\
\hline
\end{tabular}

${ }^{1}$ t-statistics are in parenthesis. $* * *, * *$, and $*$ indicate significance at the $1 \%, 5 \%$, and $10 \%$ levels respectively. 
Table 12

Test of the Reward/Incentive Hypothesis for MVA as a Determinant of Compensation, For the Sample 1871 Observations in 1992 and 1993.

\begin{tabular}{|c|c|c|c|c|}
\hline & Salary & Bonus & CashComp & TDC \\
\hline Intercept & $\begin{array}{l}-1.537 * * * \\
(-2.71)\end{array}$ & $\begin{array}{l}-1.732 * * * \\
(-4.00)\end{array}$ & $\begin{array}{l}-3.269 * * * \\
(-3.71)\end{array}$ & $\begin{array}{l}-9.697 * * * \\
(-5.00)\end{array}$ \\
\hline $\mathrm{COC}_{\mathrm{t}}$ & $\begin{array}{l}0.264 * * * \\
(5.49)\end{array}$ & $\begin{array}{l}0.172 * * * \\
(4.93)\end{array}$ & $\begin{array}{l}0.436 * * * \\
(5.77)\end{array}$ & $\begin{array}{l}0.832 * * * \\
(5.12)\end{array}$ \\
\hline$\Delta \mathrm{MVA}_{\mathrm{t}-2}$ & $\begin{array}{r}0.072 \\
(1.34)\end{array}$ & $\begin{array}{l}0.170^{* * * *} \\
(2.87)\end{array}$ & $\begin{array}{l}0.242 * * \\
(2.56)\end{array}$ & $\begin{array}{l}0.516^{* * *} \\
(2.27)\end{array}$ \\
\hline$\Delta \mathrm{MVA}_{\mathrm{t}-1}$ & $\begin{array}{c}0.254 \\
(0.00)\end{array}$ & $\begin{array}{c}0.224 \\
(0.00)\end{array}$ & $\begin{array}{c}0.478 \\
(0.00)\end{array}$ & $\begin{array}{c}0.171 \\
(0.00)\end{array}$ \\
\hline$\Delta \mathrm{MVA}_{0}$ & $\begin{array}{l}0.532 * * \\
(1.73)\end{array}$ & $\begin{array}{l}0.673 * * * \\
(3.72)\end{array}$ & $\begin{array}{l}1.205^{* * * *} \\
(2.70)\end{array}$ & $\begin{array}{l}2.687 * * * \\
(3.00)\end{array}$ \\
\hline$\Delta \mathrm{MVA}_{\mathrm{t}+1}$ & $\begin{array}{c}0.054 \\
(0.29)\end{array}$ & $\begin{array}{c}-0.058 \\
(-0.24)\end{array}$ & $\begin{array}{c}-0.004 \\
(-0.01)\end{array}$ & $\begin{array}{l}-2.450 * * * \\
(-2.74)\end{array}$ \\
\hline$\Delta \mathrm{MVA}_{\mathrm{t}+2}$ & $\begin{array}{c}0.280 \\
(1.55)\end{array}$ & $\begin{array}{r}0.059 \\
(0.28)\end{array}$ & $\begin{array}{r}0.339 \\
(0.98)\end{array}$ & $\begin{array}{l}2.172 * * * \\
(2.95)\end{array}$ \\
\hline $\begin{array}{l}\text { F-Statistic } \\
\text { (p-value) }\end{array}$ & $\begin{array}{l}55.82 \\
<0.01\end{array}$ & $\begin{array}{r}102.79 \\
<0.01\end{array}$ & $\begin{array}{l}90.26 \\
<0.01\end{array}$ & $\begin{array}{l}59.84 \\
<0.01\end{array}$ \\
\hline R-Square & 0.15 & 0.25 & 0.23 & 0.16 \\
\hline
\end{tabular}

${ }^{1} \mathrm{t}$-statistics are in parenthesis. $* * *, * *$, and $*$ indicate significance at the $1 \%, 5 \%$, and $10 \%$ levels respectively. 